
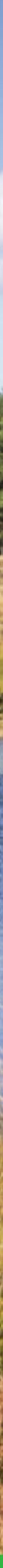

\title{
Ecosysteemdiensten in terreinen van Staatsbosbeheer
}

Kees Hendriks, Rini Schuiling, Peter Schipper, Irene Bouwma 



\section{Ecosysteemdiensten in terreinen van Staatsbosbeheer}

Kees Hendriks, Rini Schuiling, Peter Schipper, Irene Bouwma

Wageningen Environmental Research

Wageningen, juli 2018

Rapport 2893

ISSN 1566-7197 
Hendriks, Kees., Rini Schuiling, Peter Schipper en Irene Bouwma, 2018. Ecosysteemdiensten in terreinen van Staatsbosbeheer. Wageningen, Wageningen Environmental Research, Rapport 2893. 32 blz.; 2 fig.; 9 tab.; 21 ref.

Voor het jaarverslag 2017 van Staatsbosbeheer zijn vier ecosysteemdiensten in beeld gebracht. Een schatting is gemaakt van de omvang van levering van de diensten door terreinen in beheer bij Staatsbosbeheer. Geschat wordt dat de terreinen voor ca. 49 miljoen $\mathrm{m}^{3}$ bijdragen aan de jaarlijkse drinkwaterproductie in Nederland, een koolstofvoorraad hebben van ca. 38 Mton koolstof en ca. 4,8 kton fijnstof invangen. In stedelijk gebied zorgt groen beheerd door Staatsbosbeheer voor koeling. In Den Haag is het Haagse bos over het jaar heen gemiddeld $1,6{ }^{\circ} \mathrm{C}$ koeler dan de omgeving. Bij de toegepaste methode is gebruikgemaakt van literatuurgegevens en spelen oppervlakten van beheertypen een grote rol in de resultaten. Met doorontwikkeling van de methode, waarbij o.a. beheer en weersinvloeden meer gedetailleerd in de berekening worden meegenomen, kan de jaarlijkse variatie in levering van ecosysteemdiensten beter in beeld worden gebracht.

Trefwoorden: Ecosysteemdiensten, drinkwater, koolstofvoorraad, fijnstof, PM10, koeling, stedelijk groen

For use in the annual report of the Dutch State Forest Service, Staatsbosbeheer, an estimation is made of four ecosystem services delivered by forests and nature areas managed by the State Forest Service. It is roughly estimated that these terrains contribute for about 49 million $\mathrm{m}^{3}$ to the annual drinking water production in the Netherlands; 38 Mton to the bio-related carbon pool, and 4,8 kton to particulate matter deposition (PM10). Further it is estimated that the city park Haagse bos in The Hague, is about $1,6{ }^{\circ} \mathrm{C}$ cooler than the surrounding built-up area. In the method used, data from literature is used to produce key figures for ecosystem characteristics. This data together with the areas of management types, determine the results to a great extent. Improving the method by incorporating management and weather circumstances more detailed, will improve estimations of annual variation in ecosystem services deliverance.

Key words: Ecosystem services, drinking water, carbon pool, particulate matter, PM10, cooling, urban green

Dit rapport is gratis te downloaden van https://doi.org/10.18174/456304 of op www.wur.nl/environmental-research (ga naar 'Wageningen Environmental Research' in de grijze balk onderaan). Wageningen Environmental Research verstrekt geen gedrukte exemplaren van rapporten.

2018 Wageningen Environmental Research (instituut binnen de rechtspersoon Stichting Wageningen Research), Postbus 47, 6700 AA Wageningen, T 03174807 00, www.wur.nl/environmental-research. Wageningen Environmental Research is onderdeel van Wageningen University \& Research.

- Overname, verveelvoudiging of openbaarmaking van deze uitgave is toegestaan mits met duidelijke bronvermelding.

- Overname, verveelvoudiging of openbaarmaking is niet toegestaan voor commerciële doeleinden en/of geldelijk gewin.

- Overname, verveelvoudiging of openbaarmaking is niet toegestaan voor die gedeelten van deze uitgave waarvan duidelijk is dat de auteursrechten liggen bij derden en/of zijn voorbehouden.

Wageningen Environmental Research aanvaardt geen aansprakelijkheid voor eventuele schade voortvloeiend uit het gebruik van de resultaten van dit onderzoek of de toepassing van de adviezen. 


\section{Inhoud}

$\begin{array}{ll}\text { Samenvatting } & 5\end{array}$

$\begin{array}{lll}1 & \text { Inleiding } & 7\end{array}$

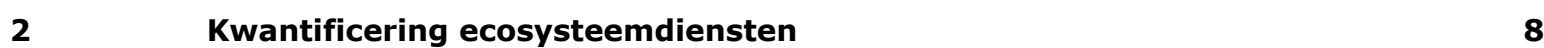

2.1 Drinkwater $\quad 8$

2.2 Koolstofvoorraad $\quad 9$

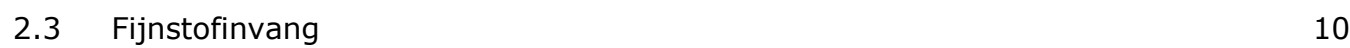

$2.4 \quad$ Koeling door groen in de stad $\quad 11$

3

$\begin{array}{ll}\text { Resultaten } & 12\end{array}$

3.1 Drinkwater $\quad 12$

3.2 Koolstofvoorraad $\quad 13$

3.3 Fijnstofdepositie 14

$\begin{array}{lll}3.4 & \text { Koeling door groen in de stad } & 15\end{array}$

$\begin{array}{llr}4 & \text { Discussie } & 16\end{array}$

$\begin{array}{llr}5 & \text { Conclusie } & 18\end{array}$

$\begin{array}{ll}\text { Literatuur } & 19\end{array}$

Bijlage 1 Vertaalsleutel Beheertypen Index NL naar Landgebruiksklassen voor waterinfiltratie en Landgebruiksklassen van LGN7 21

Bijlage 2 Vertaalsleutel beheertypen Index NL naar landgebruiksklassen voor koolstofvoorraden

Bijlage 3 Vertaalsleutel beheertypen Index NL naar landgebruiksklassen voor depositiesnelheid $\left(V_{d}\right)$ van fijnstof

$\begin{array}{lll}\text { Bijlage } 4 & \text { Drinkwater } & 27\end{array}$

Bijlage 5 Koolstofvoorraad 29

Bijlage 6 Fijnstof $\quad 30$

$\begin{array}{lll}\text { Bijlage } 7 & \text { Koeling door groen in de stad } & 31\end{array}$ 



\section{Samenvatting}

Voor het jaarverslag 2017 wil Staatsbosbeheer naast financiële en organisatorische aspecten ook aandacht besteden aan indicatoren op het gebied van natuurlijk kapitaal. Op basis van

ecosysteemdiensten kan een soort graadmeter worden ontwikkeld die over de jaren heen de prestatie op het gebied van het beheer van het natuurlijk kapitaal (behouden, beleven en benutten) weergeeft.

In dit onderzoek is voor vier ecosysteemdiensten - drinkwater, koolstofvastlegging, fijnstof invang en koeling door groen in de stad - de omvang van de dienst bepaald die door de terreinen van Staatsbosbeheer worden geleverd. Hierbij is onder andere gebruikgemaakt van kennis en data uit de literatuur, van beschikbare data van Staatsbosbeheer over de verschillende terreintypen en van data uit de Atlas Natuurlijk Kapitaal.

Het geschatte aandeel van Staatsbosbeheer terreinen in de drinkwaterproductie uit grondwater, de koolstofvoorraad en de fijnstofinvang ten opzichte van de totale oppervlakte ecosystemen in Nederland bedraagt respectievelijk 6,7, 9,8 en 9,3\%. Ten opzichte van het oppervlakteaandeel leveren de bos- en natuurterreinen van Staatsbosbeheer een hogere bijdrage aan de diensten dan het gemiddelde voor de andere ecosystemen in Nederland. Aan de koolstofvoorraad en de fijnstofinvang dragen met name de bosgebieden bij aan het hogere aandeel. Voor de drinkwaterproductie uit grondwater zijn het vooral de bos- heidegebieden die positief bijdragen.

De gehanteerde berekeningen geven een ruwe schatting van de levering van de ecosysteemdiensten. Verbetering van de methode kan door bijvoorbeeld meer systeem-specifieke data te genereren en het meer incorporeren van effecten van beheer en weersinvloeden. Met een dergelijke aanpak kan de variatie in de jaarlijkse levering van ecosysteemdiensten als gevolg van bijvoorbeeld omvormingsbeheer en beheermaatregelen gedetailleerder in beeld worden gebracht. 


\section{$1 \quad$ Inleiding}

\section{Achtergrond}

Staatsbosbeheer heeft de wens om in het jaarverslag een integrale rapportage van duurzaamheidsaspecten op te nemen. Naast de financiële en organisatorische onderdelen wil men ook aandacht besteden aan indicatoren op gebied van ecosysteemdiensten/Natuurlijk Kapitaal. Door te rapporteren over ecosysteemdiensten wordt inzicht gegeven in de prestatie op het gebied van het natuurlijk kapitaal (behouden, beleven en benutten). De vraag voor nu is om een eenvoudig begin te maken met het opnemen van informatie over geproduceerde ecosysteemdiensten in de terreinen van Staatsbosbeheer. In volgende jaren kan dit worden uitgebreid, zowel qua gedetailleerdheid van berekeningen als qua aantal ecosysteemdiensten.

\section{Doelstelling project}

De doelstelling van het project is om voor een aantal aansprekende ecosysteemdiensten kwantitatieve informatie over de omvang van de dienst te berekenen voor het jaarverslag van Staatsbosbeheer.

Als kwantitatieve informatie is één getal gewenst dat gerelateerd kan worden aan een maatschappelijk relevante dienst die door Staatsbosbeheer wordt geleverd aan de maatschappij. In een overleg met Staatsbosbeheer kwamen als interessante ecosysteemdiensten naar voren:

1. Hout (bos)

2. Biomassa (alle terreintypen)

3. Drinkwater

4. Koolstofvastlegging

5. Koeling door groen in de stad

6. Fijnstof invang door groen

7. Recreatie

8. Duurzame energie

Van een aantal diensten heeft Staatsbosbeheer zelf de benodigde informatie: hout, biomassa, recreatie en duurzame energie. De diensten drinkwater, koolstofvastlegging, koeling door groen in de stad en fijnstofinvang zijn in onderhavig project geanalyseerd.

De onderzoeksvraagstelling daarbij is het kwantificeren van de levering van de betreffende ecosysteemdienst, geleverd door de terreinen in beheer bij Staatsbosbeheer.

\section{Leeswijzer}

In hoofdstuk 2 van dit rapport is de gehanteerde methode beschreven waarmee de ecosysteemdiensten zijn gekwantificeerd. De resultaten zijn vermeld in hoofdstuk 3. In hoofdstuk 4, Discussie, worden de methode en resultaten in een bredere context besproken en worden voorstellen voor verbetering gedaan. Tot slot worden in hoofdstuk 5 de conclusies gegeven.

Voorafgaand aan dit rapport zijn de resultaten beknopt beschreven en toegelicht, zodat Staatsbosbeheer tijdig over de resultaten kon beschikken voor gebruik in het jaarverslag. De tekst van die rapportages is in de bijlagen opgenomen. 


\section{$2 \quad$ Kwantificering ecosysteemdiensten}

\section{$2.1 \quad$ Drinkwater}

Schoon en voldoende drinkwater is van essentieel belang voor de mens. In Nederland wordt ruim $60 \%$ van het drinkwater uit grondwater geproduceerd. Schoon en voldoende grondwater is daarom belangrijk voor de drinkwaterbereiding. Verschillende studies tonen echter aan dat de kwaliteit van het grondwater onder druk staat. De grootste bedreigingen van de grondwaterkwaliteit betreffen de diffuse verontreiniging door nitraat uit meststoffen, gewasbeschermingsmiddelen, nieuwe stoffen en medicijnresten (Adviescommissie Water, december 2017). Bos- en natuurgebieden dragen bij aan de drinkwaterproductie doordat regenwater in die gebieden infiltreert en het grondwater aanvult. Door het extensieve beheer van de gebieden en de filterende werking van de bodem leveren deze gebieden een hoge kwaliteit drinkwater.

Voor de berekening van de bijdrage van de gebieden van Staatsbosbeheer aan de drinkwaterproductie is als eerste stap bepaald welk deel van het in Nederland gewonnen drinkwater te relateren is aan bos- en natuurgebieden. Drinkwater wordt in Nederland geproduceerd uit grond- en oppervlaktewater. In deze studie is voor de bijdrage van de bos- en natuurgebieden van Staatsbosbeheer aan de drinkwaterproductie voor Nederland alleen de bijdrage aan grondwater in beschouwing genomen. Tussen grondwater en bos- en natuurgebieden is een redelijk eenduidige relatie. De relatie tussen gebieden en oppervlaktewater is veel minder eenduidig en daardoor lastiger te berekenen. Bovendien is veel oppervlaktewater afkomstig uit het buitenland.

In de duinen langs de kust wordt oppervlaktewater geïnfiltreerd en na filtering door duinzand weer opgepompt, het zogenaamde duinwater. In deze studie is dat als oppervlaktewater beschouwd. Langs grote rivieren en meren ligt een aantal oevergrondwaterwinningen. Het gewonnen drinkwater is grondwater, met een sterke relatie naar het oppervlaktewater, dat via de bodem aangezogen wordt naar het winpunt. In deze studie is oevergrondwater als grondwater beschouwd.

Voor gegevens over de hoeveelheid en bronnen van het geproduceerde drinkwater is gebruikgemaakt van cijfers die VEWIN publiceert (VEWIN 2016; VEWIN 2017; Baggelaar en Geudens 2017). De recentste gegevens van drinkwaterproductie zijn die uit 2016. De geproduceerde hoeveelheid drinkwater bedroeg 1.159 miljoen $\mathrm{m}^{3}$. Op basis van overzichten uit eerdere jaren (www.vewin. $\mathrm{nl}$ ) is af te leiden dat het aandeel uit grondwater gewonnen drinkwater over de jaren heen vrij constant is en ongeveer 0.642 bedraagt van de totale geproduceerde hoeveelheid drinkwater. De uit grondwater geproduceerde hoeveelheid drinkwater wordt derhalve geraamd op $1.159 * 10^{6} * 0.642=744$ miljoen $\mathrm{m}^{3}$.

Een tweede stap is het bepalen welke gebieden bijdragen aan de productie van drinkwater uit grondwater. Uit grondwater gewonnen drinkwater komt, afhankelijk van de geohydrologische situatie en de grootte van de winning, uit een meer of minder grote zone rondom de waterwinputten van de drinkwaterwinning, het zogenaamde intrekgebied. Voor de ligging en omvang van de intrekgebieden is gebruikgemaakt van de kaart Drinkwaterwinningen uit grondwater, uit de Atlas Natuurlijk Kapitaal (www.atlasnatuurlijkkapitaal.nl). De intrekgebieden omvatten in totaal ruim 915.000 ha.

De derde stap in de berekening is het bepalen van de bijdrage van de gebieden van Staatsbosbeheer aan de grondwateraanvulling in de intrekgebieden. Gebieden die binnen de grenzen van het intrekgebied liggen, dragen bij aan de grondwateraanvulling en daarmee aan de drinkwaterproductie uit grondwater. Het oppervlakteaandeel van de gebieden bepaalt grotendeels het aandeel in die bijdrage. Voor bepaling van het oppervlakteaandeel is de begrenzing van de gebieden van Staatsbosbeheer gebruikt uit het GIS-bestand van Staatsbosbeheer met beheertypen.

Daarnaast speelt de begroeiing een rol op de hoeveelheid regenwater die in de bodem infiltreert. Zo infiltreert in bos minder regenwater dan in grasland. Dit heeft te maken met de verdamping van het 
bos voor de groei en met de hoeveelheid regenwater die door boomkronen en bosvegetatie wordt ingevangen en verdampt voordat het op de grond komt. In deze studie is voor de begroeiing gecorrigeerd op basis van bekende infiltratiecijfers (Dolman et al. 2000; Hein 2011; Tabel 1).

De correctie is uitgevoerd door de oppervlakte van de verschillende landgebruikstypen binnen de intrekgebieden te vergelijken met de oppervlakte van de landgebruikstypen binnen de gebieden van Staatsbosbeheer. Voor de landgebruikstypen is de indeling van de Landgebruikskaart Nederland versie 7 (LGN7 Hazeu et al. 2014) gebruikt. De beheertypen van de Index Natuur en Landschap zoals Staatsbosbeheer die gebruikt (www.bij12.nl/de-index-natuur-en-landschap), zijn hierbij vertaald naar de LGN-indeling (Bijlage 1).

Tabel 1 Infiltratie van regenwater voor verschillende begroeiingstypen.

\begin{tabular}{ll} 
Vegetatietype & Infiltratie (m/jaar) \\
Loofbos & $0,0225^{1}$ \\
\hline Naaldbos & $0,0240^{1}$ \\
\hline Heide & $0,0424^{1}$ \\
\hline Stuifzand & $0,0656^{1}$ \\
\hline Grasland & $0,0472^{1}$ \\
\hline Wkkerland & $0,0500^{1}$ \\
\hline
\end{tabular}

1 Dolman et al. 2000

2 Hein, 2011

\subsection{Koolstofvoorraad}

Lesschen et al. (2012) geven gemiddelde waarden voor de hoeveelheid koolstof die is opgeslagen in verschillende natuurtypen (Tabel 2). De waarden zijn voor twee beheertypen aangepast. Er is een extra beheertype voor cultuurbos (o.a. hakhout, parkbos etc.) ingesteld. Deze bossen zijn veelal meer open van structuur en hebben daardoor minder biomassa en dus minder koolstofvoorraad dan gangbaar beheerd bos. Voor heide is onderscheid gemaakt tussen droge en vochtige heide op basis van de cijfers daarvoor gegeven in Lesschen et al. 2012.

Deze waarden voor de gemiddelde koolstofvoorraad per beheertype is gebruikt om de totale hoeveelheid koolstof te berekenen die in de bos- en natuurterreinen van Staatsbosbeheer is vastgelegd. De waarden voor de natuurtypen onderscheiden door Lesschen et al. (2012) zijn toegekend aan de beheertypen van de Index NL (Bijlage 2). Vervolgens zijn de totaaloppervlakten in Nederland van de verschillende beheertypen binnen de Staatsbosbeheer terreinen bepaald en vermenigvuldigd met de waarde van de koolstofvoorraad per ha.

Voor de totale koolstofvoorraad is met name het type natuur van belang. Veranderingen in de voorraad kunnen optreden door areaalverandering door bijvoorbeeld omvormingsbeheer. Daarnaast kunnen reguliere beheersmaatregelen van een type ook de koolstofvoorraad over korte of langere tijd beïnvloeden. Omdat er geen informatie eenvoudig voorhanden is of ontbreekt over de relatie tussen reguliere beheermaatregelen en koolstofvastlegging, is de invloed van beheer niet meegenomen in de berekeningen. 
De hoeveelheid vastgelegde koolstof is berekend volgens vergelijking 1 :

$\mathrm{C}_{\mathrm{SBB}}=\Sigma_{1 \ldots i}\left(\left(\mathrm{~A}\left(\mathrm{BT}_{\mathrm{i}}\right)\right) * \mathrm{C}_{\mathrm{BTi}}\right)$

Waarin:

$\mathrm{C}_{\mathrm{SBB}}=$ totale hoeveelheid koolstof vastgelegd in SBB-terreinen (ton $\mathrm{C}$ )

$A\left(B T_{i}\right)=$ Totaal oppervlak van beheertype $i$ (ha)

$\mathrm{C}_{\mathrm{BTi}}=$ gemiddelde hoeveelheid koolstof opgeslagen in beheertype $\mathrm{i}$ (ton $\mathrm{C} / \mathrm{ha}$ )

Tabel 2 Gemiddelde hoeveelheid koolstof opgeslagen in verschillende naturtypen ${ }^{1}$.

\begin{tabular}{lr} 
Natuurtype & Koolstofvoorraad (ton/ha) \\
\hline Bossen met productiefunctie & 206 \\
\hline Vochtige bossen & 239 \\
\hline Droge loofbossen & 201 \\
\hline Droge naaldbossen & 176,5 \\
\hline Cultuurbos (hakhout e.d.) & 149 \\
\hline Schorren en kwelders & 70,5 \\
\hline Rijke graslanden & 147,8 \\
\hline Vochtige graslanden & 194,5 \\
\hline Droge schraalgraslanden & 119 \\
\hline Droge heide & 96 \\
\hline Vochtige heide & 121 \\
\hline Open duin & 26 \\
\hline Zandverstuiving & 15 \\
\hline Rietmoeras & 212,5 \\
\hline Voedselarme venen & 126 \\
\hline
\end{tabular}

1 Lesschen et al. 2012

\subsection{Fijnstofinvang}

Vegetatie vangt fijnstof in uit de lucht doordat de stofdeeltjes met luchtstromen worden meegevoerd en tegen de vegetatie opbotsen of erop neerdalen. Hoe meer oppervlak (bladmassa, takken, stengels e.d.) de vegetatie heeft, hoe meer fijnstof er kan worden ingevangen. De mate waarin deeltjes worden ingevangen, hangt samen met o.a. de grootte van de deeltjes. In deze studie berekenen we depositie van fijnstof met een diameter kleiner dan $10 \mu \mathrm{m}$ (PM10) met vergelijking 2 (Powe en Willis 2004):

$\mathrm{PM} 10 \downarrow=\mathrm{A} * \mathrm{~V}_{\mathrm{d}} * \mathrm{t} * \mathrm{C} \quad(2)$

Waarin:

PM10 $\downarrow=\quad$ depositie PM10 $(\mathrm{kg})$

A $\quad=\quad$ oppervlakte beheertype $\left(\mathrm{m}^{2}\right)$

$\mathrm{V}_{\mathrm{d}} \quad=\quad$ depositiesnelheid specifiek per beheertype $(\mathrm{m} / \mathrm{s})$

$\mathrm{t} \quad=\quad \mathrm{tijd}(\mathrm{s} / \mathrm{jaar})$

C $=$ concentratie PM10 $\left(\mathrm{kg} / \mathrm{m}^{3}\right)$

De oppervlakte per beheertype is berekend met het GIS-bestand met beheertypen van Staatsbosbeheer, waarin voor alle terreinen de voorkomende beheertypen en hun oppervlakte zijn aangegeven. Voor de depositiesnelheid zijn waarden uit de literatuur afgeleid (Jones et al. 2017). Gehanteerde waarden zijn vermeld in Tabel 3. 
Tabel 3 Depositiesnelheid verschillende landgebruikstypen ${ }^{1}$.

\begin{tabular}{lll} 
Landgebruikstype & $\begin{array}{l}\text { Depositiesnelheid } \\
V_{d}(\mathrm{~m} / \mathrm{s})\end{array}$ & Aandeel landgebruik \\
\hline Loofbos & 0.00531 & \\
\hline Naaldbos & 0.00788 & \\
\hline Heide & 0.00254 & \\
\hline Stuifzand & 0.00234 & \\
\hline Grasland & 0.00254 & $50 \%$ naaldbos, $50 \%$ loofbos \\
\hline Akkerland & 0.00235 & $50 \%$ duin, $50 \%$ kwelder \\
\hline Open water & 0.00237 & $25 \%$ water, $25 \%$ grasland, $25 \%$ rietland, $25 \%$ loofbos \\
\hline Gemengd naald- loofbos & $0.00660^{2}$ & $34 \%$ akkerland, 33\% grasland, 33\% loofbos \\
\hline Duin- en kwelderlandschap & $0.00244^{2}$ & $50 \%$ akkerland, 50\% grasland \\
\hline Rivier- en moeraslandschap & $0.00319^{2}$ & \\
\hline Zand- en kalklandschap & $0.00340^{2}$ & \\
\hline Agrarisch landschap & $0.00245^{2}$ & \\
\hline Overig & 0.00244 & \\
\hline
\end{tabular}

1 Jones et al. 2017

2 Berekend op basis van oppervlakteaandeel landgebruik

De toekenning van de depositiesnelheid per landgebruikstype naar beheertype van de Index NL is weergegeven in Bijlage 3.

Voor de luchtconcentratie is gebruikgemaakt van de grootschalige depositiekaart met jaargemiddelde fijnstofconcentraties voor het jaar 2016 van het RIVM (www.rivm.nl/Depositiekaarten). De gegevens uit 2016 zijn gebruikt, omdat gegevens voor 2017 nog niet beschikbaar waren.

Ook de totale fijnstofdepositie voor Nederland is geschat met vergelijking (2). Hierbij zijn voor de landelijke oppervlakte van de verschillende ecosystemen de gegevens gebruikt van Lof et al. (2017). Als fijnstofconcentratie is de gemiddelde jaarconcentratie voor Nederland in 2016 gebruikt.

Voor de schatting van de fijnstofdepositie op het totaal van de bos- en natuurgebieden in Nederland is de oppervlakte bos- en natuurgebied gebruikt, vermeld door Lesschen et al. (2012). Voor de depositie is de gemiddelde depositie op de terreinen van Staatsbosbeheer gebruikt.

Voor de berekening van de depositie is gebruikgemaakt van standaardwaarden voor vegetatietypen uit de literatuur (Jones et al. 2017). De berekende hoeveelheid fijnstofdepositie kan afwijken van de werkelijke depositie, onder andere door variatie in windsnelheid, luchtconcentratie en bladindex van de vegetatie. De berekende depositie moet derhalve opgevat worden als een potentiële hoeveelheid.

\subsection{Koeling door groen in de stad}

Koeling door groen in de stad is niet gekwantificeerd in termen van koeling van het groen in beheer bij Staatsbosbeheer. Het koelende effect van groen in beheer bij Staatsbosbeheer als bijdrage in het totaal koelende effect is lastig in beeld te brengen. In plaats daarvan is er een beknopte literatuurraadpleging gedaan om enkele relevante feiten op een rij te zetten voor koeling door groen in de stad. Dit is geïllustreerd aan de hand van een voorbeeld van een van de gebieden in eigendom van Staatsbosbeheer, het Haagse Bos. Geraadpleegde literatuur zijn met name rapporten opgesteld in het kader van Kennis voor klimaat (www.kennisvoorklimaat.nl) en de Atlas Natuurlijk Kapitaal (www.atlasnatuurlijkkapitaal.nl). 


\section{Resultaten}

\subsection{Drinkwater}

In totaal had Staatsbosbeheer in 2017269.635 ha in beheer. Hiervan draagt 70.455 ha bos- en natuurterreinen bij aan de bescherming en productie van drinkwater dat in Nederland wordt gewonnen uit grondwater. Het areaal gebieden van Staatsbosbeheer beslaat $7,7 \%$ van het totale areaal (ruim 915.000 ha) dat bijdraagt aan drinkwaterproductie uit grondwater, de zogenaamde intrekgebieden.

De voor landgebruikstype gecorrigeerde bijdrage aan de drinkwatervoorziening bedraagt 6,7\%, 1 procentpunt lager dan het oppervlakteaandeel (Tabel 4). Dit lagere aandeel wordt veroorzaakt omdat de Staatsbosbeheergebieden relatief meer bos omvatten dan de overige in de intrekgebieden gelegen terreinen. De infiltratie van neerslag in de bodem onder bos is lager dan onder andere terreintypen zoals heide. Bos en heide dragen als beheertypen het meest bij in het drinkwateraandeel, vooral vanwege het grote oppervlakteaandeel.

Tabel 4 Oppervlak intrekgebied in Nederland (ha), aandeel drinkwater bijdrage per landgebruiksklasse (fractie), oppervlakte Staatsbosbeheer (SBB) terreinen binnen intrekgebieden (ha), aandeel landgebruiksklassen (SBB) en aandeel in drinkwater van terreinen van SBB.

\begin{tabular}{|c|c|c|c|c|c|}
\hline $\begin{array}{l}\text { Landgebruiks- } \\
\text { klasse (LUC) }\end{array}$ & $\begin{array}{l}\text { Oppervlak } \\
\text { intrek- } \\
\text { gebieden }\end{array}$ & $\begin{array}{l}\text { Drinkwater aandeel LUC } \\
\text { binnen intrekgebied }\end{array}$ & $\begin{array}{l}\text { Opp. SBB } \\
\text { binnen } \\
\text { intrekgebied }\end{array}$ & $\begin{array}{l}\text { Opp. aandeel SBB } \\
\text { binnen intrekgebied }\end{array}$ & $\begin{array}{l}\text { Drinkwater } \\
\text { aandeel SBB }\end{array}$ \\
\hline Naaldbos & 82929 & 0.062 & 19437 & 0.234 & 0.015 \\
\hline Heide & 55799 & 0.074 & 18723 & 0.336 & 0.025 \\
\hline Grasland & 332982 & 0.492 & 3721 & 0.011 & 0.006 \\
\hline Akkerland & 169218 & 0.265 & 1742 & 0.010 & 0.003 \\
\hline Kwekerijen & 9675 & 0.011 & 26 & 0.003 & 0.000 \\
\hline Hoogveen & 1601 & 0.001 & 1527 & 0.953 & 0.001 \\
\hline Bos in hoogveen & 605 & 0.000 & 518 & 0.855 & 0.000 \\
\hline Bos in moeras & 1514 & 0.001 & 540 & 0.357 & 0.000 \\
\hline Bebouwing & 120157 & 0.000 & 332 & 0.003 & 0.000 \\
\hline Water & 40595 & 0.019 & 2992 & 0.074 & 0.001 \\
\hline Overig (n.v.t.) & 1914 & 0.000 & 53 & 0.028 & 0.000 \\
\hline Totaal & 915942 & 1 & 70445 & 0.077 & 0.067 \\
\hline
\end{tabular}

Op basis van het voor vegetatietype gecorrigeerde oppervlakteaandeel wordt de bijdrage van Staatsbosbeheerterreinen aan de drinkwaterproductie gewonnen uit grondwater voor 2016, geschat op 49,6 miljoen $\mathrm{m}^{3}$ (Tabel 5). Dit is 6,7\% van de totale drinkwaterwinning uit grondwater, die in 2016 ca. 744 miljoen $\mathrm{m}^{3}$ bedroeg. De totale drinkwaterproductie in Nederland (grond-, oppervlakte- en duinwater) bedroeg in $2016 \mathrm{ca} .1159$ miljoen m³ (Baggelaar en Geudens 2017). De bijdrage van de Staatsbosbeheergebieden aan de totale drinkwaterwinning in Nederland wordt derhalve geschat op ca. $4,3 \%$. 
Tabel 5 Drinkwaterproductie in Nederland, aandeel drinkwater uit grondwater en aandeel Staatsbosbeheerterreinen aan drinkwaterproductie.

\begin{tabular}{lrr} 
Drinkwater & $\begin{array}{c}\text { Volume } \\
\left(\mathrm{m}^{3} \times 10^{6}\right)\end{array}$ & $\begin{array}{c}\text { Relatief aandeel } \\
(\%)\end{array}$ \\
\hline Productie Nederland $2016^{1}$ & 1159 & $64,2 \%$ \\
\hline Uit grondwater & 744 & $4,7 \%$ van drinkwater uit grondwater \\
\hline Aandeel SBB-terreinen & 49,6 & $4,3 \%$ van totaal drinkwater \\
\hline
\end{tabular}

1 Baggelaar en Geudens 2017

\subsection{Koolstofvoorraad}

De hoeveelheid koolstof die is vastgelegd in de terreinen van Staatsbosbeheer is geschat op 38,1 Mton (Tabel 6). Bossen hebben het grootste aandeel in de koolstofvoorraad. Daarnaast dragen (rijke) graslanden en rietmoerassen sterk bij aan de vastgelegde koolstofvoorraad. Heide, open duingebied en zandverstuivingen dragen beperkt bij. In deze gebieden is zowel de in de vegetatie als in de bodem vastgelegde hoeveelheid koolstof relatief gering.

Tabel 6 Hoeveelheid koolstof (Mton C) opgeslagen in natuurtypen van Staatsbosbeheer.

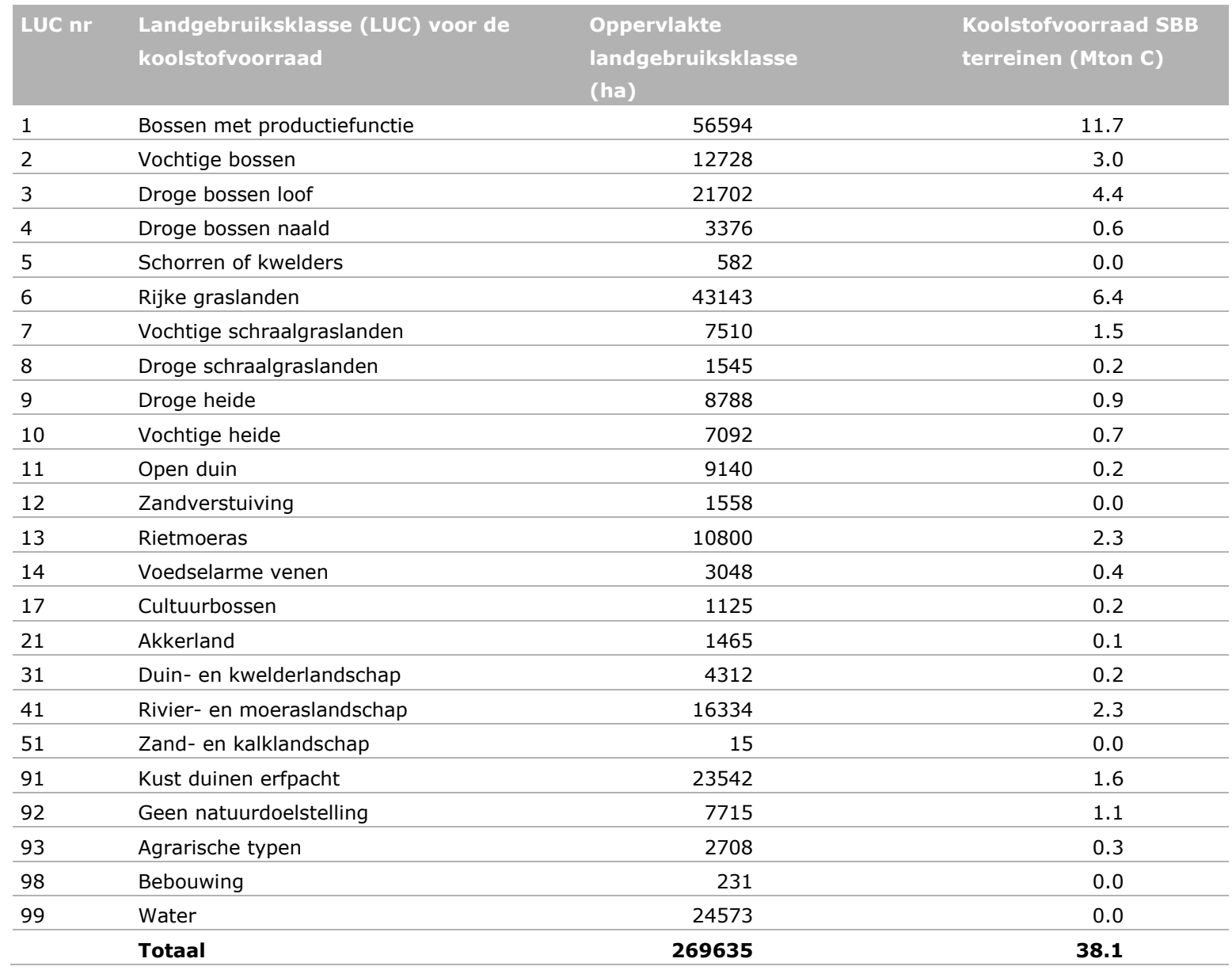

De totale hoeveelheid in bos- en natuurgebieden opgeslagen koolstof voor Nederland wordt in Lesschen et al. (2012) geschat op 88,4 Mton. Het aandeel van Staatsbosbeheer bedraagt dus ca. 43\% van de totale hoeveelheid opgeslagen in bos- en natuurterreinen in Nederland (Tabel 7). De totale koolstofvoorraad in het Nederlandse landschap (bos, natuur, agrarisch, openbaar groen) wordt door Lof et al. (2017) geschat op 388,3 Mton. Uitgaande van de landelijke hoeveelheid bedraagt de 
hoeveelheid koolstof opgeslagen in de terreinen van Staatsbosbeheer ca. 9,8\% van de totale hoeveelheid vastgelegde koolstof in Nederland (Tabel 7).

Tabel 7 Koolstofvoorraden in ecosystemen in Nederland, Nederlandse natuur en in terreinen beheerd door Staatsbosbeheer (Mton).

\begin{tabular}{lcc}
$\begin{array}{l}\text { Ecosysteem } \\
\text { Alle ecosystemen in Nederland }{ }^{1}\end{array}$ & $\begin{array}{c}\text { Koolstofvoorraad } \\
(\text { Mton) }\end{array}$ & $\begin{array}{c}\text { Relatief aandeel } \\
(\%)\end{array}$ \\
\hline Bos- en natuur in Nederland ${ }^{2}$ & 388,3 & 22,8 (t.o.v. alle ecosystemen in NL) \\
\hline Terreinen van SBB & 88,4 & 9,8 (t.o.v. alle ecosystemen in NL) \\
& 38,1 & 43,1 (t.o.v. bos- en natuur in NL) \\
\hline
\end{tabular}

1 Lof et al. 2017

2 Lesschen et al. 2012

\subsection{Fijnstofdepositie}

De berekende potentiële hoeveelheid fijnstofdepositie is geschat op 4,8 kton op basis van de luchtconcentraties voor 2016 (Tabel 8). Bossen dragen in totaal voor ruim $63 \%$ bij aan de fijnstofinvang. Dit komt doordat bossen een hoge invang hebben per ha en omdat het oppervlakteaandeel bos binnen de landgebruiksklassen groot is. Graslanden dragen bij met een kleine $14 \%$, met name vanwege het grote oppervlakteaandeel.

Tabel 8 Potentiële hoeveelheid fijnstof depositie voor landgebruiksklassen beheerd door Staatsbosbeheer.

\begin{tabular}{|c|c|c|c|}
\hline LUC nr & $\begin{array}{l}\text { Landgebruiksklasse (LUC) voor } \\
\text { fijnstof }\end{array}$ & $\begin{array}{l}\text { Oppervlakte } \\
\text { landgebruiksklasse } \\
\text { (ha) }\end{array}$ & $\begin{array}{l}\text { Potentiële fijnstofinvang } \\
\text { (PM10) } \\
\text { (kton) }\end{array}$ \\
\hline 2 & Naaldbos & 3376 & 0.13 \\
\hline 3 & Heide & 30347 & 0.38 \\
\hline 5 & Grasland & 52172 & 0.67 \\
\hline 6 & Akkerland & 1431 & 0.02 \\
\hline 7 & Open water & 24700 & 0.28 \\
\hline 11 & Gemengd naald- en loofbos & 75725 & 2.48 \\
\hline 31 & Duin- en kwelderlandschap & 4312 & 0.05 \\
\hline 91 & Erfpacht & 23542 & 0.00 \\
\hline 92 & Diversen & 7715 & 0.00 \\
\hline 93 & Agrarische typen & 2708 & 0.00 \\
\hline \multirow[t]{2}{*}{98} & Bebouwing & 56 & 0.00 \\
\hline & Totaal & 269635 & 4.84 \\
\hline
\end{tabular}

De depositie op bos- en natuurgebieden in Nederland is geschat op 9,3 kton. Het aandeel van Staatsbosbeheer daarin bedraagt ongeveer de helft (4,8 kton). Op basis van de ecosystemen onderscheiden door Lof et al. 2017 en de gemiddelde luchtconcentratie voor fijnstof in 2016 (RIVM 2017), is de hoeveelheid invang van fijnstof voor Nederland geschat op 51,9 kton. Het aandeel van de terreinen van Staatsbosbeheer bedraagt daarin ca. 9,3\% (Tabel 9). 
Tabel 9 Schatting van de potentiële invang van fijnstof door ecosystemen in Nederland, Nederlandse bos- en natuurterreinen en door terreinen beheerd door Staatsbosbeheer (kton).

\begin{tabular}{lcc} 
Ecosysteem & $\begin{array}{c}\text { Potentiële invang } \\
\text { fijnstof } \\
\text { (Kton) }\end{array}$ \\
Alle ecosystemen in Nederland ${ }^{1}$ & 51,9 & 100 \\
\hline Bos- en natuur in Nederland ${ }^{2}$ & 9,3 & 18,0 (t.o.v. alle ecosystemen in NL) \\
\hline Terreinen van SBB ${ }^{3}$ & 4,8 & 9,3 (t.o.v. alle ecosystemen in NL) \\
& & 51,8 (t.o.v. bos- en natuur in NL)
\end{tabular}

1 oppervlakte volgens Lof et al. 2017

2 oppervlakte volgens Lesschen et al. 2012

3 oppervlakte volgens SBB

\subsection{Koeling door groen in de stad}

Stedelijke gebieden zijn o.a. door verharding, remming van wind en menselijke activiteiten warmer dan hun omgeving. Dit wordt het stedelijk hitte-eilandeffect genoemd (Figuur 3.1). Stedelijk groen geeft verkoeling in warme perioden door verdamping van water en door het bieden van schaduw. De koelende bijdrage van een specifieke groen element in een stad aan de totale stedelijke temperatuur is met de huidige kennis nog weinig nauwkeurig in beeld te brengen. Wel zijn er globale schattingen bekend van effecten van groen op de stedelijke temperatuur. Zo vermeldt Döpp (2011) dat vergroten van het aandeel openbaar groen in een wijk met $10 \%$ overdag leidt tot een verlaging van de temperatuur met $2,0^{\circ} \mathrm{C}$ en 's nachts met $1,2{ }^{\circ} \mathrm{C}$. Ook wordt vermeld dat parken in steden substantieel kunnen bijdragen aan koeling van de stad. Het verschil in luchttemperatuur tussen parken en hun stedelijke omgeving kan 1 tot $6{ }^{\circ} \mathrm{C}$ bedragen. Onderzoek laat een wisselend effect zien in de mate van koeling en de afstand tot waar de koeling merkbaar is. De afstand varieert van $20 \mathrm{~m}$ tot meer dan $1 \mathrm{~km}$.

Het Haagse bos, een park in het centrum van Den Haag dat wordt beheerd door Staatsbosbeheer, is zo'n koele plek in de stad. Voor dit park (bosgebied) is berekend dat de jaargemiddelde temperatuur ten opzichte van de omgeving zo'n $1,6{ }^{\circ} \mathrm{C}$ lager is (www.atlasnatuurlijkkapitaal.nl).

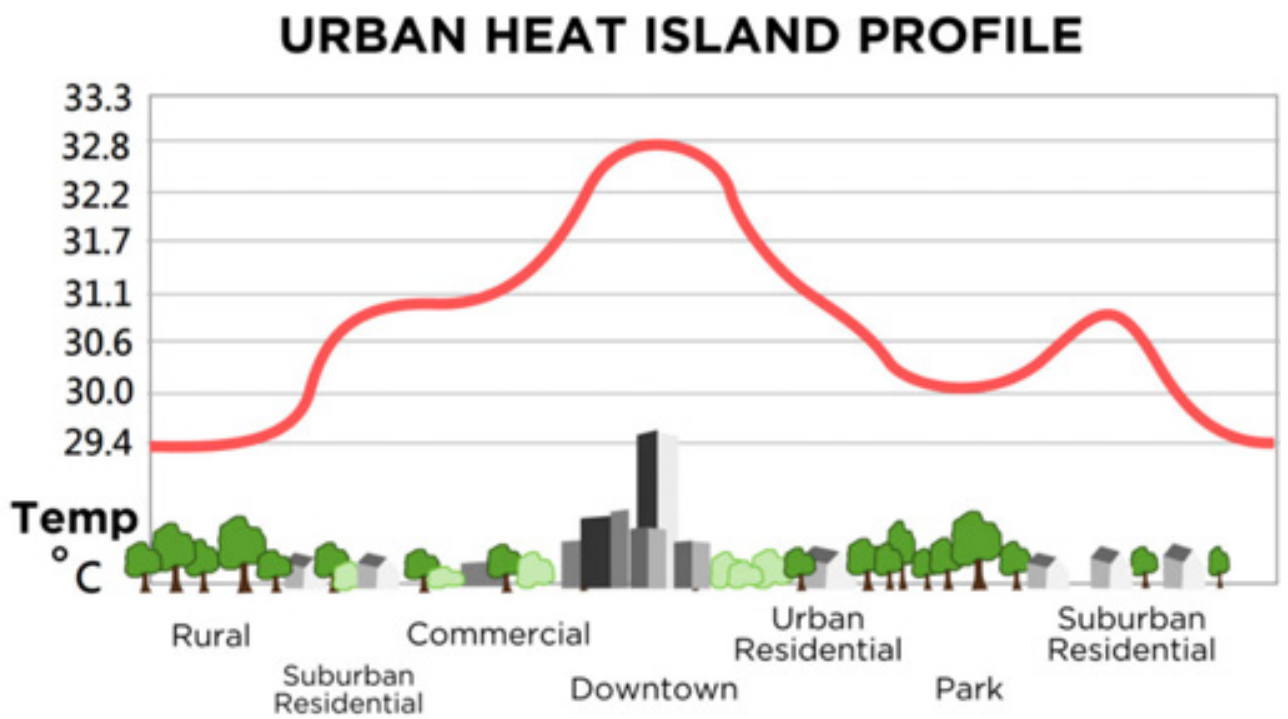

Figuur 3.1 Het hitte-eilandeffect (bron: Urban heat island.svg). 


\section{Discussie}

De in dit rapport gepresenteerde cijfers voor ecosysteemdiensten zijn grove schattingen van de omvang van de diensten. Bij de berekeningen is gebruikgemaakt van gegevens uit de literatuur en waar nodig en mogelijk zijn deze vertaald naar de Nederlandse situatie en naar de terreinen van Staatsbosbeheer. Voor een deel zijn de gegevens afkomstig van gemodelleerde gegevens, omdat meetgegevens ontbreken. De cijfers dienen dan ook met de nodige voorzichtigheid gebruikt te worden, zeker als het gaat om gebruik in absolute zin.

De gevolgde werkwijze voor de berekening van de bijdrage aan de drinkwaterproductie is een eerste poging om de bijdrage van bos- en natuurgebieden voor drinkwater op landelijke schaal te berekenen. Een andere aanpak om op nationaal niveau deze ecosysteemdienst te berekenen, is nog niet bekend. Liekens et al. (2013) vermelden in hun studie naar kwantificeren van ecosysteemdiensten het volgende over de ecosysteemdienst waterproductie: "Het is mogelijk om de rol aan te tonen die het ecosysteem heeft om water te leveren en de waterbalans in evenwicht te houden. Hiervoor is gedetailleerde informatie nodig over de kenmerken van het gebied en informatie over de watercyclus (hydrologische modellen). Daarnaast is de baat ook afhankelijk van de vraag naar water in een specifieke regio. Deze dienst is dus zeer moeilijk te vatten in een generieke en eenvoudig toepasbare methode." In hun rapport wordt geen methode uitgewerkt om de ecosysteemdienst drinkwater te berekenen. De Knegt (2014) stelt dat al het in Nederland gebruikte drinkwater uit ecosystemen afkomstig is en maakt daarbij geen onderscheid tussen water afkomstig uit Nederlandse of buitenlandse gebieden. De bijdrage van ecosystemen aan de drinkwatervoorziening berekenen zij door te kijken naar de zuiverende werking van ecosystemen. Bij gebruik van oppervlaktewater wordt het water in een aantal stappen technisch gezuiverd voordat het als drinkwater gebruikt kan worden. De bijdrage van ecosystemen wordt door De Knegt (2014) beschouwd door naar het aantal zuiveringsstappen te kijken dat nodig is om water op drinkwaterkwaliteit te brengen. Als er weinig stappen nodig zijn, wordt de zuiverende bijdrage van het ecosysteem als hoog beschouwd. Voor grondwatersystemen wordt het zuiverend vermogen op $60 \%$ geschat en voor oppervlaktewatersystemen op $20 \%$. Met deze aanpak zou de bijdrage berekend worden voor het gehele intrekgebied, en niet specifiek voor het areaal dat hierbinnen beheerd wordt door Staatsbosbeheer. Dus, alhoewel de in onderhavige studie gehanteerde berekening als een grove benadering moet worden gezien, is het voor zover bekend de eerste keer dat een poging is ondernomen om de bijdrage van bos- en natuurgebieden aan de ecosysteemdienst drinkwater in Nederland te kwantificeren. De doelstelling van de Europese Kader Richtlijn Water (KRW) richt zich op het behoud van de huidige kwaliteit van bronnen voor menselijke consumptie, met als doel de zuiveringsinspanning te beperken tot het verwijderen van stoffen die van nature aanwezig zijn. Deze doelstelling is breder dan drinkwater, omdat deze specifieke doelstelling voor schoon water ook geldt voor de bereiding van bier, frisdrank en andere voedingsmiddelen. De arealen van SBB liggen deels ook in de intrekgebieden van grondwater dat voor de productie van bier, frisdrank en andere voedingsmiddelen wordt gebruikt. Dit is in deze studie niet meegenomen in de berekening.

De gevolgde methode voor de berekening van de koolstofvoorraad is overgenomen uit Lesschen et al. (2012). Ook de in die studie gebruikte kengetallen zijn overgenomen. Deze kengetallen zijn gemiddelde koolstofvoorraden voor de onderscheiden landgebruikstypen. De door Staatsbosbeheer gebruikte beheertypen volgen die van de Index NL en zijn gedetailleerder dan de landgebruikstypen van Lesschen et al. (2012). Toekennen van de beheertypen aan de landgebruiksklassen betekent een vergroting van de onnauwkeurigheid van de schatting. Echter, er zijn geen gegevens beschikbaar over de koolstofvoorraad op niveau van de beheertypen. Verfijning van de gegevens van Lesschen et al. (2012) naar de beheertypen is wel mogelijk, maar binnen de context van deze studie was dat niet haalbaar. Wel zijn de kengetallen van Lesschen et al. (2012) voor twee landgebruikstypen verfijnd, n.l. bij heide is onderscheid gemaakt tussen vochtige en droge heide. De studie van Lesschen et al. (2012) geeft daar bruikbare informatie over. Verder is bij de bossen een extra categorie toegevoegd voor bossen met een cultuurhistorisch karakter zoals hakhout, parkbos, eendenkooien etc. Deze 
bossen hebben veelal een andere structuur dan gangbaar opgaand bos en zijn veelal opener met minder biomassa. Daarom is voor deze bossen een lagere koolstofvoorraad aangehouden dan het gemiddelde voor alle bostypen tezamen.

Het berekenen van fijnstofdepositie is onderwerp van (wetenschappelijk) debat. De discussie spitst zich toe op enerzijds het belang van de ingevangen hoeveelheid versus luchtconcentraties fijnstof (o.a. Wesseling et al. 2011) en anderzijds op de werking van groen bij het afvangen (Pronk et al. 2013). Voor gezondheidswinst is het van belang dat de luchtconcentratie fijnstof vermindert. Bij berekening van de invang van fijnstof wordt een massa berekend die door de vegetatie wordt ingevangen. Het is echter onduidelijk wat dit voor de luchtconcentratie betekent. Het is ook niet zonder meer om te rekenen. Studies naar effecten van vegetatie op de luchtconcentratie in praktijksituaties laten geen eenduidige vermindering van luchtconcentraties zien. Enerzijds omdat metingen in het veld vaak aan kleine groenelementen worden verricht waarbij veel randeffecten optreden, anderzijds omdat de invloed van onderzochte vegetatie vaak beperkt is en vanwege de geringe omvang de meting daardoor een hoge onzekerheid bevat. Zo berekende De Maerschalck (2011) een verlaging van de fijnstofconcentratie in stedelijke omgeving voor een dubbele bomenrij van ca. $0,2 \%$ bij een luchtconcentratie van $25 \mu \mathrm{g} / \mathrm{m}^{3}$. Er zijn echter ook effecten bekend dat luchtconcentraties toenemen door het zogenaamde street-canyon-effect, waarbij fijnstof minder verdunt door de wind-remmende werking van groen (Wesseling et al. 2011). Studies naar grootschalig groen laten wel een duidelijk effect zien van vermindering van de fijnstofconcentratie. McDonald et al. (2007) berekenden een potentiële reductie van ca. $10 \%$ bij een bebossing van ca. $50 \%$ voor een gebied van $900 \mathrm{~km}^{2}$ in de West-Midlands in het Verenigd Koninkrijk. Het positieve effect van verminderen van de fijnstofconcentratie staat niet ter discussie. Buisman et al. (2013) zeggen hierover: "Er kunnen geen veilige niveaus worden aangetoond waarbij geen schadelijke gezondheidseffecten van fijnstof optreden. Dit houdt in dat er op basis van epidemiologische studies geen buitenluchtconcentratie is aan te geven waar beneden geen gezondheidseffecten worden gevonden. Daarom zullen er ook beneden de huidige grenswaarden voor fijnstof in de buitenlucht gezondheidseffecten kunnen optreden. Dit betekent dat er gezondheidswinst mag worden verwacht bij elke microgram minder fijnstof, ongeacht de aard of samenstelling van het fijnstof. Wel is bekend dat niet al het fijnstof even schadelijk is en dat beleid dus kan prioriteren op basis van toxiciteit en blootstellingscenario's." Vanuit deze gedachte kan gesteld worden dat ieder groenelement dat bijdraagt aan de vermindering van de hoeveelheid fijnstof, bijdraagt aan het verbeteren van de kwaliteit van de leefomgeving.

Bij de gehanteerde berekeningen voor de bijdragen aan drinkwater, koolstofvoorraad en fijnstofinvang is geen rekening gehouden met variatie in de tijd. Zo is er geen rekening gehouden met verandering in het beheer van een bepaald natuurtype of met verandering in oppervlakte tussen beheertypen over de tijd, noch met veranderingen in het totale areaal aan bos- en natuurtypen. Het is mogelijk om meer jaarlijkse variatie in de methoden op te nemen, echter dat vergt meer ruimtelijke informatie over areaalsveranderingen en beheersvormen. Op die wijze zou een soort graadmeter ontwikkeld kunnen worden die de veranderingen in natuurlijk kapitaal weergeeft. Binnen het huidige tijdsbestek voor deze studie was een dergelijke aanpak niet haalbaar.

Verder ontbreken inzicht en methoden veelal nog voor analyses van ecosysteemdiensten, waarin bijvoorbeeld ook beheer en weersinvloeden tot uiting komen; deze meer gedetailleerde methoden kunnen worden ontwikkeld, maar dit vergt tijd. Met een dergelijke aanpak kan de variatie in de jaarlijkse prestatie van Staatsbosbeheer op gebied van ecosysteemdiensten gedetailleerder in beeld worden gebracht. 


\section{$5 \quad$ Conclusie}

De resultaten laten zien dat de terreinen die worden beheerd door Staatsbosbeheer bijdragen aan de levering van ecosysteemdiensten in Nederland.

Het aandeel door Staatsbosbeheer beheerde bos- en natuurterreinen bedraagt 269.635 ha, dit is 6,5\% van de totale oppervlakte agrarische en natuurlijke ecosystemen in Nederland (4.151.000 ha).

Het geschatte aandeel van Staatsbosbeheerterreinen in de drinkwaterproductie uit grondwater, de koolstofvoorraad en de fijnstofinvang ten opzichte van de totale oppervlakte ecosystemen in Nederland, bedraagt respectievelijk $6,7 \%, 9,8 \%$ en $9,3 \%$. Ten opzichte van het oppervlakteaandeel leveren de bos- en natuurterreinen van Staatsbosbeheer dus een hogere bijdrage aan de diensten dan de andere ecosystemen in Nederland. Voor de koolstofvoorraad en de fijnstofinvang dragen met name de bosgebieden bij aan het hogere aandeel. Voor de drinkwaterproductie uit grondwater zijn het vooral de bos- en heidegebieden die positief bijdragen.

Voor drinkwater moet opgemerkt worden dat de berekening alleen betrekking heeft op drinkwater uit grondwater. Als gekeken wordt naar de totale drinkwaterproductie, dus ook het drinkwater gewonnen uit oppervlaktewater, dan is het aandeel van de Staatsbosbeheerterreinen $4,3 \%$. Het oppervlaktewater is echter (groten)deels afkomstig uit het buitenland en dus niet direct aan Nederlandse ecosystemen te relateren.

De in deze studie gebruikte methode kan gebruikt worden als een soort graadmeter om de jaarlijkse prestatie op gebied van natuurlijk kapitaal grof in beeld te brengen. Het kent echter beperkingen in de nauwkeurigheid daarvan. Indien men de jaarlijkse verandering van natuurlijk kapitaal in beeld wil brengen, verdient het de voorkeur de ecosysteemdiensten gedetailleerder in beeld te brengen. De methode die daarvoor nodig is, moet echter nog wel ontwikkeld worden. 


\section{Literatuur}

Adviescommissie Water (19 december 2017). Advies Grondwater. AcW-2017/310926

Atlas Natuurlijk Kapitaal www.atlasnatuurlijkkapitaal.nl

Baggelaar, P.K. en P.J.J.G. Geudens (2017). Prognoses en scenario's drinkwatergebruik in Nederland. Rapport Icastat en Vewin.

Buijsman, E., F.R. Cassee, P.H. Fischer et al. (2013). Dossier Fijnstof. Bilthoven, Rijksinstituut voor Volksgezondheid en Milieu (RIVM).

Claessens, J., N.G.F.M. van der Aa, P. Groenendijk en L. Renaud (2017). Effecten van het landelijk mestbeleid op de grondwaterkwaliteit in grondwaterbeschermingsgebieden. Bilthoven, RIVM, RIVM Rapport 2016-0199.

De Knegt, B. (ed.) (2014). Graadmeter Diensten van Natuur; Vraag, aanbod, gebruik en trend van goederen en diensten uit ecosystemen in Nederland. Wettelijke Onderzoekstaken Natuur \& Milieu, WOt-technical report 13 .

De Maerschalck, B., Peter Vos, Stijn Janssen, Tim Op't Eyndt (2011). Envi-met Modelanalyse: Effecten van Vegetatie op de Lokale Luchtkwaliteit in een Street Canyon, Studie uitgevoerd in opdracht van: CROW, VITO 2011/RMA/R/40.

Dolman, H., E. Moors, J. Elbers, W. Snijders en Philip Hamaker (2000). Het waterverbruik van bossen in Nederland. Wageningen, Alterra.

Döpp, S. ed. (2011). Kennismontage Hitte en Klimaat in de stad. Utrecht, Climate Proof Cities Consortium.

Hazeu, G.W.; Schuiling, C.; Dorland, G.J. van; Roerink, G.J.; Naeff, H.S.D.; Smidt, R.A. (2014). Landelijk Grondgebruiksbestand Nederland versie 7 (LGN7) : vervaardiging, nauwkeurigheid en gebruik. Wageningen, Alterra, Wageningen-UR, Alterra-rapport 2548.

Hein, L. (2011). Economic benefits generated by protected areas: the case of the Hoge Veluwe forest, the Netherlands. Ecology and Society 16(2): 13.

Jones, L., M. Vieno, D. Morton et al. (2017). Developing Estimates for the Valuation of Air Pollution Removal in Ecosystem Accounts. Final Report. Edinburgh, UK, Centre for Ecology and Hydrology $(\mathrm{CEH})$.

Klok, E.J., S. Schaminée, J. Duyzer en G.J. Steeneveld (2012). De stedelijke hitte-eilanden van Nederland in kaart gebracht met satellietbeelden. Utrecht, TNO, publicatie TNO-060-UT-201201117.

Lesschen, J.P., H. Heesmans, J. Mol-Dijkstra, A. van Doorn, E. Verkaik, I. van den Wyngaert, P. Kuikman (2012). Mogelijkheden voor koolstofvastlegging in de Nederlandse landbouw en natuur. Wageningen, Alterra, Alterra rapport 2396.

Lof, M., S. Schenau, R. de Jong, R. Remme, C. Graveland en L. Hein (2017). The SEEA EEA Carbon Account for the Netherlands. The Hague/Wageningen, CBS/Wageningen University, Report. 
McDonald, A.G., W.J. Bealey, D. Fowler, U. Dragosits, U. Skiba, R.I. Smith, R.G. Donovan, H.E. Brett, C.N. Hewit and E. Nemitz (2007). Quantifying the effect of urban tree planting on concentrations and depositions of PM10 in two UK conurbations. Atmospheric Environment (41): 8455-8467.

Powe, N.A. en K.G. Willis (2004). Mortality and morbidity benefits of air polution (SO2 and PM10) absorption attributable to woodland in Britain. Journ. of Env. Man. (70): 119-128.

RIVM (2017). GDN Depositiebestanden achterliggende jaren.

https://www.rivm.nl/Onderwerpen/G/GCN GDN kaarten 2016/Depositiekaarten/Cijfers achter d e depositiekaarten:xstsT jYRve1RNQrWkwnLA/GDN depositiebestanden achterliggende jaren (geraadpleegd 1403 2018).

Vewin (2016). Kerngegevens 2015. Den Haag, Vewin.

Vewin (2017). Kerngegevens 2016. Den Haag, Vewin.

Wessling, J., S. van der Zee en A. van Overveld (2011). Het effect van vegetatie op de luchtkwaliteit. Bilthoven, RIVM, RIVM Rapport 680705019/2011. 


\section{Bijlage 1 Vertaalsleutel Beheertypen Index NL naar Landgebruiks- klassen voor waterinfiltratie en Landgebruiksklassen van LGN7}

\begin{tabular}{|c|c|c|c|c|c|}
\hline Code W & $\begin{array}{l}\text { Landgebruiksklasse } \\
\text { waterinfiltratie }\end{array}$ & $\begin{array}{l}\text { Landgebruiksklasse } \\
\text { LGN7 }\end{array}$ & $\begin{array}{l}\text { Klasse } \\
\text { Index NL }\end{array}$ & $\begin{array}{l}\text { Infiltratie } \\
\text { (m/jaar) }\end{array}$ & Opmerking \\
\hline 1 & Loofbos & $\begin{array}{l}11 \text { Loofbos } \\
20 \text { bos in primair bebouwd } \\
22 \text { bos in secundair } \\
\text { bebouwd }\end{array}$ & $\begin{array}{l}\text { N14.03 } \\
\text { N15.02 } \\
\text { N16.01 } \\
\text { N16.02 } \\
\text { N16.03 } \\
\text { N16.04 } \\
\text { N17.01 } \\
\text { N17.02 } \\
\text { N17.03 } \\
\text { N17.06 } \\
\text { L01.02 } \\
\text { L01.03 } \\
\text { L01.04 } \\
\text { L01.07 } \\
\text { L01.08 } \\
\text { L01.16 } \\
\text { A13.01 }\end{array}$ & 0.225 & \\
\hline 2 & Naaldbos & 12 Naaldbos & N15.01 & 0.240 & $\begin{array}{l}18 \% \text { donker naaldbos } \\
82 \% \text { licht naaldbos }\end{array}$ \\
\hline 3 & Heide & $\begin{array}{l}32 \text { duinen lage veg } \\
33 \text { duinen hoge veg } \\
34 \text { duinheide } \\
36 \text { heide } \\
37 \text { matige vergraste heide } \\
38 \text { sterk vergraste heide } \\
45 \text { natuurgrasland }\end{array}$ & $\begin{array}{l}\text { N06.04 } \\
\text { N07.01 } \\
\text { N08.03 } \\
\text { N08.04 } \\
\text { N10.01 } \\
\text { N10.02 } \\
\text { N11.01 } \\
\text { N12.06 } \\
\text { L01.05 } \\
\text { L01.06 } \\
\text { A13.02 }\end{array}$ & 0.424 & 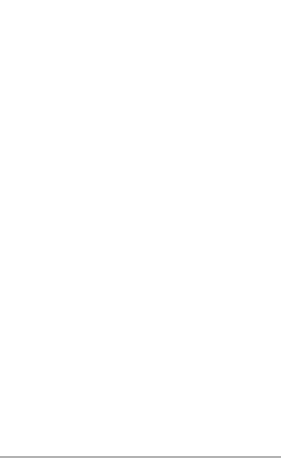 \\
\hline 4 & Stuifzand & $\begin{array}{l}24 \text { kale grond in bebouwd } \\
31 \text { open zand in kust } \\
35 \text { open zand }\end{array}$ & $\begin{array}{l}\text { N07.02 } \\
\text { N08.01 } \\
\text { N08.02 }\end{array}$ & 0.656 & \\
\hline 5 & Hoogveen & 39 hoogveen & N06.03 & 0.287 & $\begin{array}{l}50 \% \text { heide } \\
50 \% \text { water }\end{array}$ \\
\hline 6 & Bos in hoogveen & 40 bos in hoogveen & 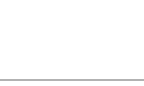 & 0.188 & $\begin{array}{l}50 \% \text { loofbos } \\
50 \% \text { water }\end{array}$ \\
\hline 7 & Overig moeras & 41 overige moeras & $\begin{array}{l}\text { N05.01 } \\
\text { N06.02 } \\
\text { A01.05 }\end{array}$ & 0.287 & $\begin{array}{l}50 \% \text { heide } \\
50 \% \text { water }\end{array}$ \\
\hline 8 & Rietvegetatie & 42 rietvegetatie & $\begin{array}{l}\text { N05.02 } \\
\text { N06.01 } \\
\text { A11.02 }\end{array}$ & 0.287 & $\begin{array}{l}50 \% \text { heide } \\
50 \% \text { water }\end{array}$ \\
\hline 9 & Bos in moeras & 43 bos in moeras & $\begin{array}{l}\text { N14.01 } \\
\text { N14.02 } \\
\text { N17.04 } \\
\text { N17.05 }\end{array}$ & 0.188 & $\begin{array}{l}50 \% \text { loofbos } \\
50 \% \text { water }\end{array}$ \\
\hline
\end{tabular}




\begin{tabular}{|c|c|c|c|c|c|}
\hline Code W & $\begin{array}{l}\text { Landgebruiksklasse } \\
\text { waterinfiltratie }\end{array}$ & $\begin{array}{l}\text { Landgebruiksklasse } \\
\text { LGN7 }\end{array}$ & $\begin{array}{l}\text { Klasse } \\
\text { Index NL }\end{array}$ & $\begin{array}{l}\text { Infiltratie } \\
\text { (m/jaar) }\end{array}$ & Opmerking \\
\hline 14 & Grasland & $\begin{array}{l}1 \text { Agrarisch gras } \\
9 \text { boomgaarden } \\
23 \text { gras in primair bebouwd } \\
28 \text { gras in secundair } \\
\text { bebouwd }\end{array}$ & $\begin{array}{l}\text { N12.01 } \\
\text { N12.02 } \\
\text { N12.03 } \\
\text { N12.04 } \\
\text { N13.01 } \\
\text { L01.09 } \\
\text { L02.03 } \\
\text { A01.01 } \\
\text { A01.03 } \\
\text { A02.01 } \\
\text { A02.02 } \\
\text { A11.01 } \\
\text { A11.03 }\end{array}$ & 0.472 & \\
\hline 21 & Akkerland & $\begin{array}{l}2 \text { mais } \\
3 \text { aardappelen } \\
4 \text { bieten } \\
5 \text { granen } \\
6 \text { overig landbouwgewas } \\
10 \text { bloembollen } \\
62 \text { fruitkwekerijen }\end{array}$ & $\begin{array}{l}\mathrm{N} 12.05 \\
\mathrm{~A} 01.02 \\
\mathrm{~A} 12.01 \\
\mathrm{~A} 12.02 \\
\mathrm{~A} 12.03\end{array}$ & 0.500 & $\begin{array}{l}\text { Bovenkant infiltratie van } \\
\text { grasland vanwege braak } \\
\text { periode }\end{array}$ \\
\hline 22 & Kwekerijen & 61 boomkwekerijen & & 0.363 & $\begin{array}{l}50 \% \text { loofbos } \\
50 \% \text { akker }\end{array}$ \\
\hline 23 & A-typen & Agrarisch & A-typen & 0.486 & $\begin{array}{l}50 \% \text { gras } \\
50 \% \text { akker }\end{array}$ \\
\hline 31 & $\begin{array}{l}\text { Duin- en } \\
\text { Kwelderlandschap }\end{array}$ & & N01.02 & 0.540 & $\begin{array}{l}50 \% \text { stuifzand } \\
50 \% \text { heide }\end{array}$ \\
\hline 41 & $\begin{array}{l}\text { Rivier- en } \\
\text { moeraslandschap }\end{array}$ & & N01.03 & 0.317 & $\begin{array}{l}25 \% \text { water } \\
25 \% \text { graslanden } \\
25 \% \text { rietmoeras=heide } \\
25 \% \text { loofbos }\end{array}$ \\
\hline 51 & Zand- en kalklandschap & & N01.04 & 0.399 & $\begin{array}{l}33 \% \text { akkerland } \\
33 \% \text { graslanden } \\
33 \% \text { loofbos }\end{array}$ \\
\hline 96 & Bebouwing & $\begin{array}{l}18 \text { bebouwing in primair } \\
\text { bebouwd } \\
19 \text { bebouwing in secundair } \\
\text { bebouwd } \\
25 \text { hoofd- en spoorwegen } \\
26 \text { bebouwing buitengebied }\end{array}$ & $\begin{array}{l}\text { L02.01 } \\
\text { L02.02 } \\
\text { L03.01 }\end{array}$ & n.v.t. & $\begin{array}{l}\text { Drinkwater hoeft niet } \\
\text { berekend te worden voor } \\
\text { deze categorie }\end{array}$ \\
\hline 97 & Water & 16 zoetwater & $\begin{array}{l}\text { N02.01 } \\
\text { N03.01 } \\
\text { N04.01 } \\
\text { N04.02 } \\
\text { N06.06 } \\
\text { L01.01 } \\
\text { A14.01 } \\
\text { A14.02 }\end{array}$ & 0.150 & \\
\hline 98 & Diversen (S98) & Diversen & S98 & 0.368 & $\begin{array}{l}\text { Gemiddelde van alle Inf } \\
\text { cijfers }\end{array}$ \\
\hline 99 & Diversen (S99) & Erfpacht & S99 & 0.540 & $\begin{array}{l}50 \% \text { stuifzand } \\
50 \% \text { heide }\end{array}$ \\
\hline 91 & Overig & $\begin{array}{l}8 \text { glastuinbouw } \\
30 \text { kwelders }\end{array}$ & $\begin{array}{l}\text { N01.01 } \\
\text { N04.03 } \\
\text { N04.04 } \\
\text { N09.01 }\end{array}$ & nvt & $\begin{array}{l}\text { Drinkwater hoeft niet } \\
\text { berekend te worden voor } \\
\text { deze categorie }\end{array}$ \\
\hline
\end{tabular}




\section{Bijlage 2 Vertaalsleutel beheertypen Index NL naar landgebruiks- klassen voor koolstofvoorraden}

\begin{tabular}{|c|c|c|c|c|}
\hline Code C & $\begin{array}{l}\text { Landgebruiksklasse voor } \\
\text { koolstofvoorraad }\end{array}$ & $\begin{array}{l}\text { Code } \\
\text { Index NL }\end{array}$ & Toelichting Bij12 & $\begin{array}{l}\text { Koolstofvoorraad } \\
\text { (ton/ha) }\end{array}$ \\
\hline \multirow[t]{4}{*}{1} & Bossen met productiefunctie & N16.01 & Droog bos met productie & 206 \\
\hline & & N16.02 & Vochtig bos met productie & \\
\hline & & N16.03 & Droog bos met productie & \\
\hline & & N16.04 & Vochtig bos met productie & \\
\hline \multirow[t]{4}{*}{2} & Vochtige bossen & N14.01 & Rivier- en beekbegeleidend bos (vochtig) & 239 \\
\hline & & N14.02 & Hoog- en laagveenbos (vochtig) & \\
\hline & & $\mathrm{N} 14.03$ & Haagbeuken- en essenbos (vochtig) & \\
\hline & & L01.03 & Elsensingel & \\
\hline \multirow[t]{6}{*}{3} & Droge loofbossen & N15.02 & Dennen-, eiken, en beukenbossen (droog) & 201 \\
\hline & & L01.02 & Houtwal en houtsingel & \\
\hline & & L01.04 & Bossingel en bosje & \\
\hline & & L01.07 & Laan & \\
\hline & & L01.16 & Bossingel & \\
\hline & & A13.01 & Bomenrij en singel & \\
\hline 4 & Droge naaldbossen & N15.01 & Duinbos (droog) & 176,5 \\
\hline 5 & Schorren of kwelders & N09.01 & Schor of kwelder & 70,5 \\
\hline \multirow[t]{19}{*}{6} & Rijke graslanden & N12.01 & Bloemdijk & 147,8 \\
\hline & & N12.02 & Kruiden- en faunarijk grasland & \\
\hline & & N12.03 & Glanshaverhooiland & \\
\hline & & N12.04 & Zilt- en overstromingsgrasland & \\
\hline & & N12.06 & Ruigteveld & \\
\hline & & N13.01 & Vochtig weidevogelgrasland & \\
\hline & & N13.02 & Wintergastenweide & \\
\hline & & L01.08 & Knotboom & \\
\hline & & L01.09 & Hoogstamboomgaard & \\
\hline & & L02.03 & Historische tuin & \\
\hline & & A01.01 & Weidevogelgebieden & \\
\hline & & A01.03 & Ganzenfoerageergebied & \\
\hline & & A01.04 & Insectenrijk grasland & \\
\hline & & A01.05 & Foerageerrand bever & \\
\hline & & A02.01 & Botanisch waardevol grasland & \\
\hline & & A11.01 & Weidevogelgrasland in open landschap & \\
\hline & & A11.02 & $\begin{array}{l}\text { Weidevogelland met riet of opgaande } \\
\text { begroeiing }\end{array}$ & \\
\hline & & A11.03 & Open grasland voor overwinterende vogels & \\
\hline & & A13.02 & Struweel en ruigte & \\
\hline \multirow[t]{2}{*}{7} & Vochtige schraalgraslanden & N10.01 & Nat schraalland & 194,5 \\
\hline & & N10.02 & Vochtig hooiland & \\
\hline 8 & Droge schraalgraslanden & N11.01 & Droog schraalland & 119 \\
\hline 9 & Droge heide & N07.01 & Droge heide & 96 \\
\hline 10 & Vochtige heide & N06.04 & Vochtige Heide & 121 \\
\hline \multirow[t]{3}{*}{11} & Open duin & N08.02 & Open duin & 26 \\
\hline & & N08.03 & Vochtige duinvallei & \\
\hline & & N08.04 & Duinheide & \\
\hline \multirow[t]{2}{*}{12} & Zandverstuiving & N07.02 & Zandverstuiving & 15 \\
\hline & & N08.01 & Strand en embryonaal duin & \\
\hline \multirow[t]{2}{*}{13} & Rietmoeras & N05.01 & Moeras & 212,5 \\
\hline & & N05.02 & Gemaaid rietland & \\
\hline 14 & Voedselarme venen & N06.01 & Veenmosrietland en moerasheide & 126 \\
\hline
\end{tabular}




\begin{tabular}{|c|c|c|c|c|}
\hline Code C & $\begin{array}{l}\text { Landgebruiksklasse voor } \\
\text { koolstofvoorraad }\end{array}$ & $\begin{array}{l}\text { Code } \\
\text { Index NL }\end{array}$ & Toelichting Bij12 & $\begin{array}{l}\text { Koolstofvoorraad } \\
\text { (ton/ha) }\end{array}$ \\
\hline & & N06.02 & Trilveen & \\
\hline & & N06.03 & Hoogveen & \\
\hline \multirow[t]{6}{*}{17} & Cultuurbossen & N17.01 & Vochtig hakhout en middenbos & 149 \\
\hline & & N17.02 & Droog hakhout & \\
\hline & & N17.03 & Park en stinzenbos & \\
\hline & & N17.04 & Eendenkooi & \\
\hline & & N17.05 & Wilgengriend & \\
\hline & & N17.06 & Vochtig en hellinghakhout & \\
\hline \multirow[t]{8}{*}{21} & Akkerland & N12.05 & Kruiden- en faunarijke akker & 94 \\
\hline & & L01.05 & Knip- of scheerheg & \\
\hline & & L01.06 & Struweelhaag & \\
\hline & & $\mathrm{A} 01.02$ & Akkerfaunagebied & \\
\hline & & $\mathrm{A} 02.02$ & Botanisch waardevol akkerland & \\
\hline & & A12.01 & $\begin{array}{l}\text { Open akkerland voor broedende } \\
\text { akkervogels }\end{array}$ & \\
\hline & & A12.02 & $\begin{array}{l}\text { Open akkerland voor overwinterende } \\
\text { akkervogels }\end{array}$ & \\
\hline & & A12.03 & Akkeland met hamsters & \\
\hline 31 & Duin- en kwelderlandschap & N01.02 & Duin- en kwelderlandschap & $\begin{array}{l}50 \text { ( } 50 \% \text { open duin, } \\
50 \% \text { kwelder) }\end{array}$ \\
\hline 41 & Rivier- en moeraslandschap & N01.03 & Rivier- en moeraslandschap & $\begin{array}{l}140,3 \text { ( } 25 \% \text { water, } \\
25 \% \text { rijk grasland, } \\
25 \% \text { rietmoeras, } \\
25 \% \text { vochtig bos) }\end{array}$ \\
\hline 51 & Zand- en kalklandschap & N01.04 & Zand- en kalklandschap & $\begin{array}{l}147,6 \text { (34\% akkerland, } \\
33 \% \text { rijk grasland, } \\
33 \% \text { loofbos) }\end{array}$ \\
\hline \multirow[t]{3}{*}{98} & Bebouwing & L02.01 & Fortterrein & 0 \\
\hline & & L02.02 & Historisch bouwwerk en erf & \\
\hline & & L03.01 & Aardwerk en groeve & \\
\hline \multirow[t]{12}{*}{99} & Water & N01.01 & Zee en wad & 0 \\
\hline & & N02.01 & Rivieren & \\
\hline & & N03.01 & Beek en bron & \\
\hline & & N04.01 & Kranswierwater & \\
\hline & & N04.02 & Zoete plas & \\
\hline & & N04.03 & Brakwater & \\
\hline & & N04.04 & Afgesloten zeearm & \\
\hline & & N06.05 & Zwakgebufferd ven & \\
\hline & & N06.06 & Zuur ven of hoogveenven & \\
\hline & & L01.01 & Poel en klein historisch water & \\
\hline & & A14.01 & Watergang & \\
\hline & & A14.02 & Poel & \\
\hline
\end{tabular}




\section{Bijlage 3 Vertaalsleutel beheertypen Index NL naar landgebruiks- klassen voor depositiesnelheid $\left(V_{d}\right)$ van fijnstof}

\begin{tabular}{|c|c|c|c|c|}
\hline Code F & $\begin{array}{l}\text { Landgebruiksklasse } \\
\text { voor fijnstof }\end{array}$ & $\begin{array}{l}\text { Code Index } \\
\text { NL }\end{array}$ & Omschrijving Index NL & $\begin{array}{l}\text { Depositiesnelheid } \\
\text { Vd }(\mathrm{m} / \mathrm{s})\end{array}$ \\
\hline \multirow[t]{15}{*}{1} & Loofbos & N14.01 & Rivier- en beekbegeleidend bos (vochtig) & 0.00531 \\
\hline & & N14.02 & Hoog- en laagveenbos (vochtig) & \\
\hline & & N14.03 & Haagbeuken- en essenbos (vochtig) & \\
\hline & & N17.01 & Vochtig hakhout en middenbos & \\
\hline & & N17.02 & Droog hakhout & \\
\hline & & N17.03 & Park en stinzenbos & \\
\hline & & N17.05 & Wilgengriend & \\
\hline & & N17.06 & Vochtig en hellinghakhout & \\
\hline & & L01.02 & Houtwal en houtsingel & \\
\hline & & L01.03 & Elsensingel & \\
\hline & & L01.04 & Bossingel en bosje & \\
\hline & & L01.07 & Laan & \\
\hline & & L01.08 & Knotboom & \\
\hline & & L01.16 & Bossingel & \\
\hline & & A13.01 & Bomenrij en singel & \\
\hline 2 & Naaldbos & N15.01 & Duinbos (droog) & 0.00788 \\
\hline \multirow[t]{13}{*}{3} & Heide & N05.01 & Moeras & 0.00254 \\
\hline & & N05.02 & Gemaaid rietland & \\
\hline & & N06.01 & Veenmosrietland en moerasheide & \\
\hline & & N06.02 & Trilveen & \\
\hline & & N06.03 & Hoogveen & \\
\hline & & N06.04 & Vochtige Heide & \\
\hline & & N07.01 & Droge heide & \\
\hline & & N08.03 & Vochtige duinvallei & \\
\hline & & N08.04 & Duinheide & \\
\hline & & N09.01 & Schor of kwelder & \\
\hline & & L01.05 & Knip- of scheerheg & \\
\hline & & L01.06 & Struweelhaag & \\
\hline & & A13.02 & Struweel en ruigte & \\
\hline \multirow[t]{3}{*}{4} & Onbegroeid & N07.02 & Zandverstuiving & 0.00234 \\
\hline & & N08.01 & Strand en embryonaal duin & \\
\hline & & N08.02 & Open duin & \\
\hline \multirow[t]{15}{*}{5} & Grasland & N10.01 & Nat schraalland & 0.00254 \\
\hline & & N10.02 & Vochtig hooiland & \\
\hline & & N11.01 & Droog schraalland & \\
\hline & & N12.01 & Bloemdijk & \\
\hline & & N12.02 & Kruiden- en faunarijk grasland & \\
\hline & & N12.03 & Glanshaverhooiland & \\
\hline & & N12.04 & Zilt- en overstromingsgrasland & \\
\hline & & N12.06 & Ruigteveld & \\
\hline & & N13.01 & Vochtig weidevogelgrasland & \\
\hline & & N13.02 & Wintergastenweide & \\
\hline & & L01.09 & Hoogstamboomgaard & \\
\hline & & L02.03 & Historische tuin & \\
\hline & & A01.01 & Weidevogelgebieden & \\
\hline & & A01.03 & Ganzenfoerageergebied & \\
\hline & & A01.04 & Insectenrijk grasland & \\
\hline
\end{tabular}




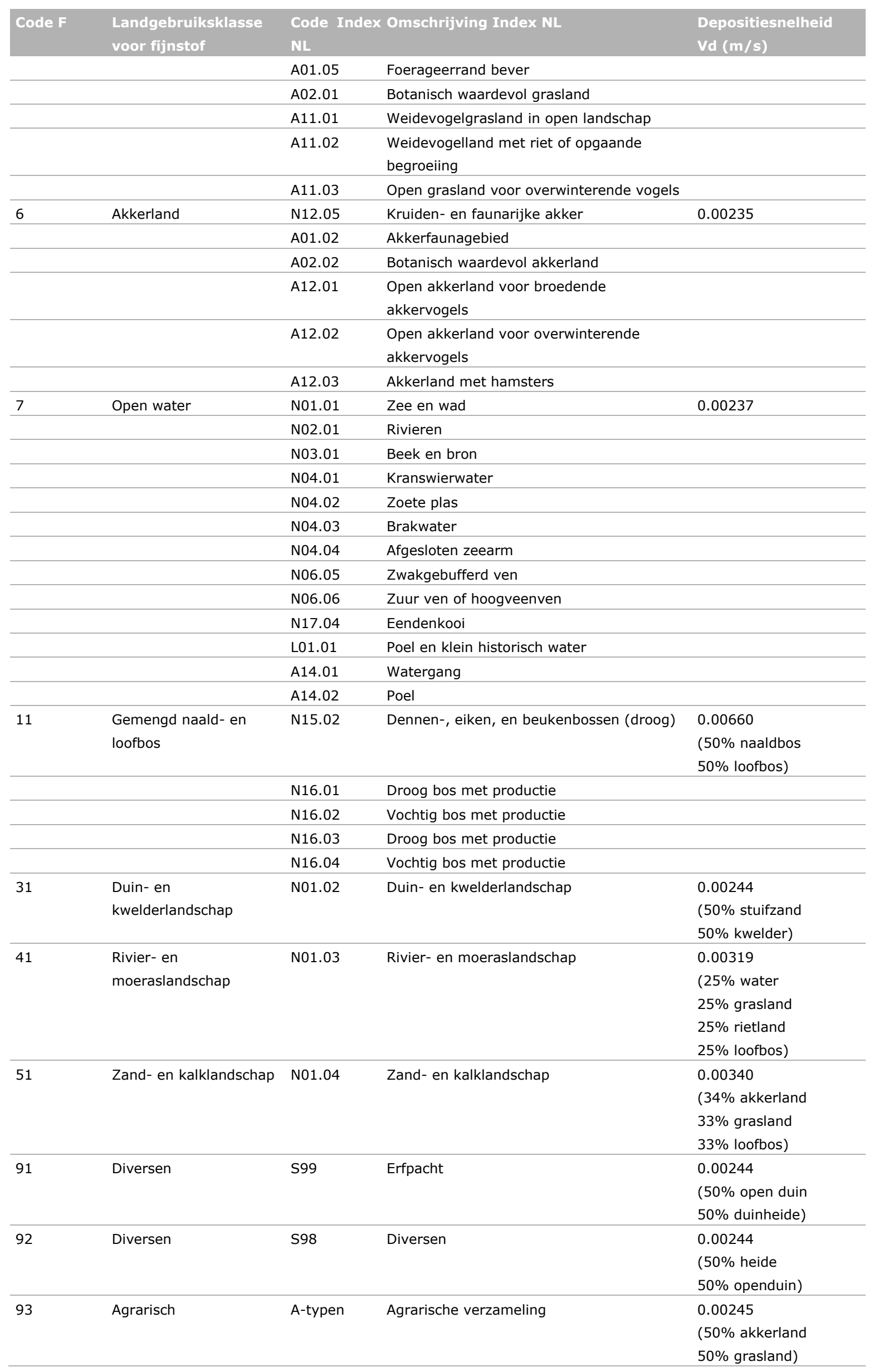




\section{Bijlage 4 Drinkwater}

Schoon en voldoende drinkwater is van essentieel belang voor de mens. In Nederland wordt drinkwater gewonnen uit grond- en oevergrondwater en uit oppervlaktewater. Het aandeel drinkwater uit grondwater is ongeveer 64\%. De grondwatervoorraad wordt voortdurend aangevuld met regenwater. Een deel van de neerslag die valt, wordt door planten onderschept of gebruikt voor de verdamping die nodig is voor de groei. Het resterende deel infiltreert in de bodem en kan het grondwater aanvullen. Infiltratie kan via alle onverharde oppervlakken. Bos- en natuurgebieden dragen bij aan de grondwateraanvulling en leveren een hoge kwaliteit drinkwater, omdat er in deze gebieden een beperkt risico is op verontreiniging en niet gemest wordt. In de periode 2010-2014 werd in een kwart van de grondwaterbeschermingsgebieden de drinkwaternorm voor nitraat overschreden. Nitraat spoelt uit de bodem o.a. vanuit bemeste landbouwgronden.

De bijdrage aan de drinkwatervoorziening door bos- en natuurgebieden is het eenduidigst voor de winning uit grondwater. Oppervlaktewater in Nederland komt voor een groot deel uit het buitenland en is dus niet te relateren aan de Nederlandse ecosystemen.

Omwille van de tijd en beschikbare data is de bijdrage van bos- en natuurgebieden aan de drinkwatervoorziening hier berekend op een vrij grove en eenvoudige wijze. Om de bijdragen van bosen natuurgebieden aan de drinkwatervoorziening in Nederland te berekenen, is uitgegaan van het areaal van de intrekgebieden van pompstations, waar grondwater wordt onttrokken voor de drinkwaterbereiding. De intrekgebieden omvatten in totaal ruim 915.000 ha.

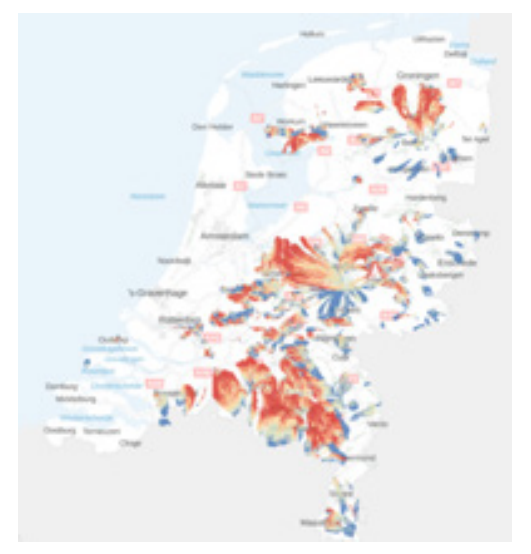

Figuur B4.1 Ligging intrekgebieden in Nederland (Bron: www.atlasnatuurlijkkapitaal.nl / Deltares).

Voor de bos- en natuurgebieden van Staatsbosbeheer is berekend wat hun oppervlakteaandeel is binnen deze intrekgebieden. Gegevens over infiltratie per vegetatietype uit de literatuur zijn gerelateerd aan de beheertypen van Staatsbosbeheer. De infiltratiecapaciteit van de vegetatietypen is gebruikt als maat om het oppervlakteaandeel van een bepaald vegetatietype te corrigeren. Omdat bosgebieden bijvoorbeeld een lagere infiltratiecapaciteit hebben dan graslanden, dragen deze laatste verhoudingsgewijs per hectare meer bij en wordt het oppervlakteaandeel naar boven gecorrigeerd en voor bossen naar beneden.

70.455 ha bos- en natuurterreinen van Staatsbosbeheer dragen bij aan de bescherming en productie van drinkwater dat in Nederland wordt gewonnen uit grondwater. Dit is $7,7 \%$ van het totale areaal (ruim 900.000 ha) dat bijdraagt aan drinkwaterproductie uit grondwater. 
De voor vegetatietype gecorrigeerde bijdrage aan de drinkwatervoorziening bedraagt 6,7\%, 1 procentpunt lager dan het oppervlakteaandeel. Dit wordt veroorzaakt omdat de Staatsbosbeheergebieden relatief meer bos omvatten dan de overige in de intrekgebieden gelegen terreinen. De infiltratie van neerslag onder bos is lager dan onder andere terreinen zoals landbouwgebieden.

Op basis van het voor vegetatietype gecorrigeerde oppervlakteaandeel, wordt de bijdrage van Staatsbosbeheerterreinen aan de drinkwaterproductie gewonnen uit grondwater voor 2016, geschat op 49,6 miljoen $\mathrm{m}^{3}$. Dit is $6,7 \%$ van de totale drinkwaterwinning uit grondwater die in $2016 \mathrm{ca}$. 744 miljoen $\mathrm{m}^{3}$ bedroeg. De totale drinkwaterproductie in 2016 (grond-, oppervlakte- en duinwater) bedroeg ca. 1159 miljoen $\mathrm{m}^{3}$. De bijdrage van de Staatsbosbeheergebieden aan de totale drinkwaterwinning in Nederland wordt derhalve geschat op ca. 4,3\%. 


\section{Bijlage 5 Koolstofvoorraad}

Koolstofdioxide $\left(\mathrm{CO}_{2}\right)$ is een gas dat een belangrijke rol speelt bij klimaatverandering. Het gas komt onder andere vrij bij verbranden van fossiele brandstoffen. De begroeiing in bos- en natuurterreinen neemt $\mathrm{CO}_{2}$ op uit de atmosfeer en legt dit vast in de planten, struiken, bomen en in de bodem (humus). Op deze manier dragen natuurgebieden bij aan het verminderen van het $\mathrm{CO}_{2}$-gehalte in de atmosfeer en het aanpakken van de klimaatverandering.

De $\mathrm{CO}_{2}$ wordt in de vegetatie vastgelegd in koolstofverbindingen (o.a. cellulose, lignine) en de zuurstof wordt deels weer door de plant uitgeademd. De koolstofvastlegging in vegetatie wordt meestal in hoeveelheid vastgelegde koolstof uitgedrukt (ton $\mathrm{C} / \mathrm{ha}$ ). Klimaatdoelen spreken echter over $\mathrm{CO}_{2}$-reductie. De hoeveelheid vastgelegde koolstof kan voor dat doel ook worden gerelateerd aan de hoeveelheid $\mathrm{CO}_{2}$ die in het verleden daarvoor uit de atmosfeer is opgenomen (ton $\mathrm{CO}_{2} / \mathrm{ha}$ ).

Op basis van literatuur zijn schattingen gemaakt van de hoeveelheid koolstof voor de verschillende bos- en natuurterreinen van Staatsbosbeheer. Hierbij is uitgegaan van de oppervlakten van beheertypen in 2017. In totaal is in deze gebieden 38,1 Mton Koolstof opgeslagen (Tabel 6 pag. 13). De totale hoeveelheid in bos- en natuurgebieden opgeslagen hoeveelheid koolstof voor Nederland wordt door Lesschen et al. (2012) geschat op 88,4 Mton $^{1}$. Het aandeel van opgeslagen hoeveelheid koolstof in de terreinen van Staatsbosbeheer bedraagt dus ca. $43 \%$ van de totale hoeveelheid opgeslagen in bos- en natuurterreinen in Nederland.

De totale koolstof voorraad in het Nederlandse landschap (bos, natuur, agrarisch, openbaar groen) wordt in door Lof et al. (2017) geschat op 388,3 Mton. De berekening wijze voor het totaal van Nederland is enigszins anders dan onze berekening. Het vergelijk moet derhalve met enige voorzichtigheid gehanteerd worden. Uitgaande van de landelijke hoeveelheid, bedraagt de hoeveelheid koolstof opgeslagen in de terreinen van Staatsbosbeheer derhalve ca. $10 \%$ van de totale hoeveelheid vastgelegde koolstof in Nederland.

\footnotetext{
${ }^{1}$ In termen van $\mathrm{CO}_{2}$ is dit:

Totale hoeveelheid vastgelegd $\mathrm{CO}_{2}$ in SBB-terreinen: 139,9 Mton $\mathrm{CO}_{2}$.

Totale hoeveelheid vastgelegd $\mathrm{CO}_{2}$ in het Nederlandse landschap: $1424 \mathrm{Mton} \mathrm{CO}_{2}$.

De percentages blijven onveranderd bij berekeningen van $\mathrm{C}$ en $\mathrm{CO}_{2}$.
} 


\section{Bijlage 6 Fijnstof}

Fijnstof is een schadelijke stof voor de gezondheid van mensen. Te veel fijnstof leidt tot aantasting van de luchtwegen en kan leiden tot vroegtijdig overlijden. In Nederland voldoen de gemiddelde jaarconcentraties over het algemeen aan de wettelijke normen. Plaatselijk kunnen echter hoge pieken voorkomen. Voor fijnstof geldt dat iedere vermindering van deeltjes in de lucht een verbetering is.

Begroeiing kan met de bladeren fijnstof uit de lucht filteren. Hierbij geldt dat hoe meer bladoppervlak een plant heeft, hoe meer fijnstof de plant kan invangen. Bomen hebben een groot bladoppervlak en hebben daarom een grote invangcapaciteit. Bossen en parken worden niets voor niets groene longen genoemd. Lage vegetatie zoals gras vangt ook fijnstof in, alleen in mindere mate dan struiken en bomen.

Het berekenen van de invang van fijnstof is onderwerp van wetenschappelijke discussie. Een deel van de parameters die worden gebruikt, worden theoretisch afgeleid. Bovendien bestaan er verschillende formules met een verschillende mate van detail. De meer complexe formules bevatten veel parameters. In deze studie is gerekend met een relatief eenvoudige formule die gangbaar is voor studies op nationaal schaalniveau. Daarnaast speelt nog de discussie welke deeltjes het relevantst zijn: PM10, PM2.5 of ultrafijnstof. In deze studie is gekozen om PM10 te berekenen. Dit is een in veel studies gangbare maat voor fijnstof.

Over het nut van het berekenen van depositiecijfers wordt een wetenschappelijk discussie gevoerd. Voor gezondheid is de luchtconcentratie van belang. Door de complexiteit van atmosferische processen is de hoeveelheid depositie niet direct om te rekenen naar een verminderde concentratie. Wel geeft de depositie een beeld waar ecosystemen een belangrijke rol spelen bij afvangen van fijnstof. En hierbij geldt dat iedere vermindering van fijnstofdeeltjes in de lucht een verbetering is.

Op basis van literatuurgegevens is een schatting gemaakt van de hoeveelheid fijnstof (PM10) die natuurgebieden potentieel kunnen invangen. De potentiële invang van de bos- en natuurgebieden van Staatsbosbeheer wordt geschat op 4.8 kton fijnstof op basis van de luchtconcentratie in 2016. Deze hoeveelheid is grofweg de helft van alle fijnstof die wordt ingevangen in de Nederlandse natuur.

De totale potentiële invang van fijnstof in de Nederlandse landschappen is globaal geschat op $52 \mathrm{kton}$ PM10. Het aandeel van Staatsbosbeheer daarin bedraagt ca. 9\%. 


\section{Bijlage 7 Koeling door groen in de stad}

Door de vele verharding, grote bevolkingsdichtheid en menselijke activiteiten warmen steden op tot zogenaamde Stedelijke Hitte Eilanden (Urban Heat Islands) die veel warmer zijn dan hun omgeving. Op warme dagen kan dit verschil oplopen tot wel $9{ }^{\circ} \mathrm{C}$. Gemiddeld voor de 73 grootste steden van Nederland is het overdag $2,9^{\circ} \mathrm{C}$ en $2,4{ }^{\circ} \mathrm{C}$ 's nachts. Door klimaatverandering komen hoge temperaturen vaker voor en warmen steden verder op, waardoor de vraag naar koeling in de stad in de toekomst zal toenemen.

Stedelijk groen geeft verkoeling in warme perioden. Bomen geven schaduw, waar het dus koeler is dan in de zon. Ook verdampen bomen en planten water, wat een verkoelend effect heeft op de omgeving. Hierdoor vormen parken op warme dagen aangename oasen voor mensen in de stad die op zoek zijn naar verkoeling en ontspanning. Vergroten van het aandeel openbaar groen in een wijk met $10 \%$ leidt overdag tot een verlaging van de temperatuur met $2,0^{\circ} \mathrm{C}$ en 's nachts met $1,2{ }^{\circ} \mathrm{C}$ ( Klok et al. 2012).

Parken in steden dragen substantieel bij aan koeling van de stad. Het verschil in luchttemperatuur tussen parken en hun stedelijke omgeving kan 1-6 ${ }^{\circ} \mathrm{C}$ bedragen. Deze koele parken zijn de tegenhanger van de Urban Heath Islands en worden ook wel Park Cool Islands genoemd. Via luchtstroming kan de koele lucht vanuit het park de omliggende bebouwde omgeving koelen. Onderzoek laat een wisselend effect zien in de mate van koeling en de afstand tot waar de koeling merkbaar is. De afstand varieert van $20 \mathrm{~m}$ tot meer dan $1 \mathrm{~km}$.

Het Haagse bos, een park in het centrum van Den Haag dat beheerd wordt door Staatsbosbeheer, is zo'n koele plek in de stad. Voor dit park (bosgebied) is berekend dat de jaargemiddelde temperatuur ten opzichte van de omgeving zo'n $1,6^{\circ} \mathrm{C}$ lager is. De koelende werking maakt het een aangename plek om te verblijven op warme dagen. 
Wageningen Environmental Research Postbus 47

6700 AA Wageningen

T 0317480700

www.wur.nl/environmental-research

Wageningen Environmental Research Rapport 2893

ISSN 1566-7197
De missie van Wageningen University \& Research is 'To explore the potential of nature to improve the quality of life'. Binnen Wageningen University \& Research bundelen Wageningen University en gespecialiseerde onderzoeksinstituten van Stichting Wageningen Research hun krachten om bij te dragen aan de oplossing van belangrijke vragen in het domein van gezonde voeding en leefomgeving. Met ongeveer 30 vestigingen, 5.000 medewerkers en 10.000 studenten behoort Wageningen University \& Research wereldwijd tot de aansprekende kennisinstellingen binnen haar domein. De integrale benadering van de vraagstukken en de samenwerking tussen verschillende disciplines vormen het hart van de unieke Wageningen aanpak. 



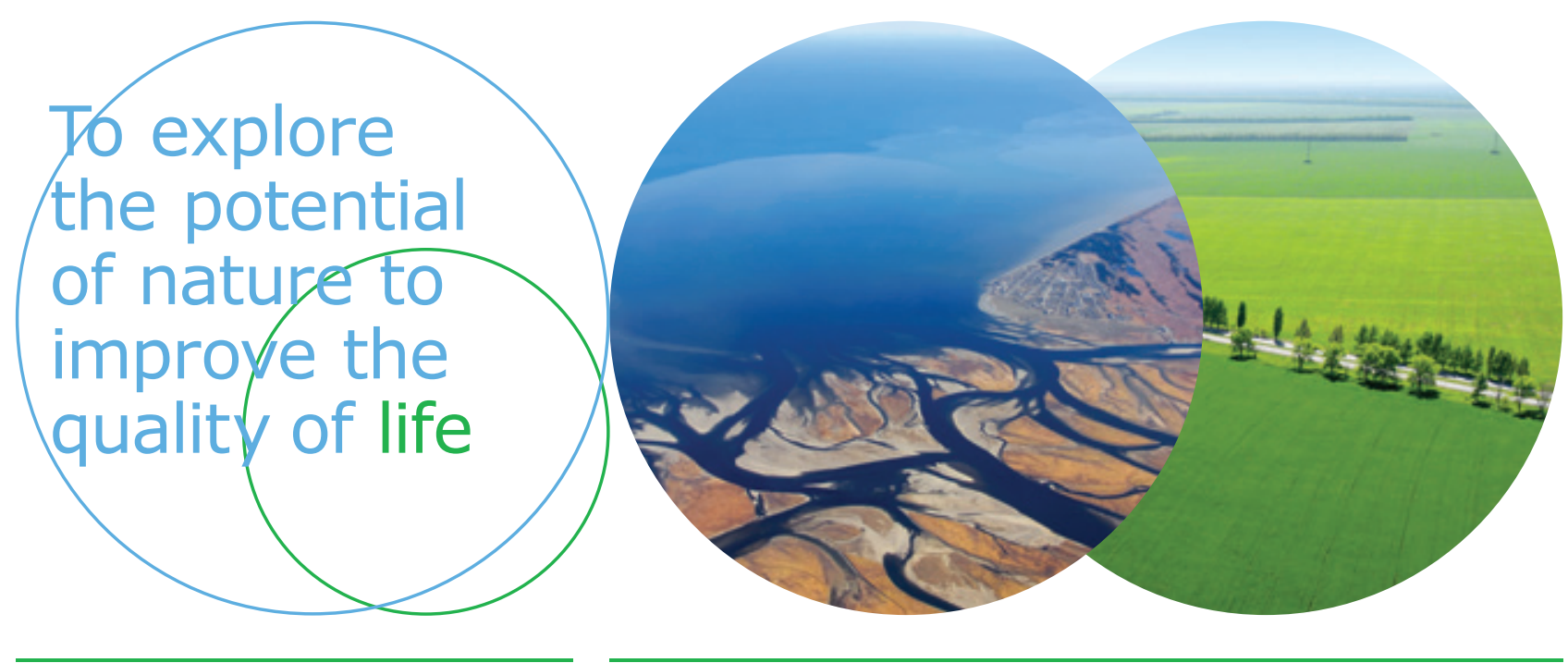

Wageningen Environmental Research Postbus 47

$6700 \mathrm{AB}$ Wageningen

T 317480700

www.wur.nl/environmental-research

Rapport 2893

ISSN 1566-7197
De missie van Wageningen University \& Research is 'To explore the potential of nature to improve the quality of life'. Binnen Wageningen University \& Research bundelen Wageningen University en gespecialiseerde onderzoeksinstituten van Stichting Wageningen Research hun krachten om bij te dragen aan de oplossing van belangrijke vragen in het domein van gezonde voeding en leefomgeving. Met ongeveer 30 vestigingen, 5.000 medewerkers en 10.000 studenten behoort Wageningen University \& Research wereldwijd tot de aansprekende kennisinstellingen binnen haar domein. De integrale benadering van de vraagstukken en de samenwerking tussen verschillende disciplines vormen het hart van de unieke Wageningen aanpak. 